\title{
Stereochemical Geometries and Photoluminescence in Pseudo-Halido-Zinc(II) Complexes. Structural Comparison between the Corresponding Cadmium(II) Analogs
}

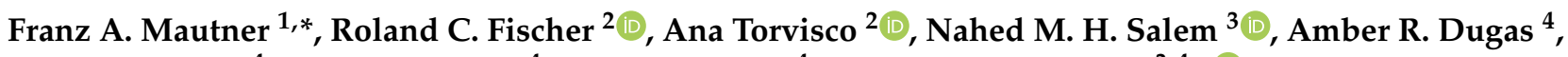 \\ Shelby F. Aaron ${ }^{4}$, Sushant P. Sahu ${ }^{4}$, Febee R. Louka ${ }^{4}$ and Salah S. Massoud ${ }^{3,4, * \mathbb{D}}$ \\ 1 Institut für Physikalische and Theoretische Chemie, Technische Universität Graz, A-8010 Graz, Austria \\ 2 Institut für Anorganische Chemie, Technische Universität Graz, Stremayrgasse 9/V, A-8010 Graz, Austria; \\ roland.fischer@tugraz.at (R.C.F.); ana.torviscogomez@tugraz.at (A.T.) \\ 3 Department of Chemistry, Faculty of Science, Alexandria University, Moharam Bey, Alexandria 21511, Egypt; \\ nahed_s@yahoo.com \\ 4 Department of Chemistry, University of Louisiana at Lafayette, P.O. Box 43700, Lafayette, LA 70504, USA; \\ amber.dugas2@louisiana.edu (A.R.D.); shelby.aaron1@louisiana.edu (S.F.A.); \\ sushant.sahu@louisiana.edu (S.P.S.); febee.louka@louisiana.edu (F.R.L.) \\ * Correspondence: mautner@tugraz.at (F.A.M.); ssmassoud@louisiana.edu (S.S.M.); \\ Tel.: +43-316-4873-8234 (F.A.M.); +1-337-482-5672 (S.S.M.); \\ Fax: +43-316-4873-8225 (F.A.M.); +1-337-482-5676 (S.S.M.)
}

\section{check for}

updates

Citation: Mautner, F.A.; Fischer, R.C.; Torvisco, A.; Salem, N.M.H.; Dugas, A.R.; Aaron, S.F.; Sahu, S.P.; Louka, F.R.; Massoud, S.S. Stereochemical Geometries and Photoluminescence in Pseudo-Halido-Zinc(II) Complexes. Structural Comparison between the Corresponding Cadmium(II) Analogs. Inorganics 2021, 9, 53. https:// doi.org/10.3390/inorganics 9070053

Academic Editor: Wolfgang Linert

Received: 15 June 2021

Accepted: 7 July 2021

Published: 9 July 2021

Publisher's Note: MDPI stays neutral with regard to jurisdictional claims in published maps and institutional affiliations.

Copyright: (c) 2021 by the authors. Licensee MDPI, Basel, Switzerland. This article is an open access article distributed under the terms and conditions of the Creative Commons Attribution (CC BY) license (https:/ / creativecommons.org/licenses/by/ $4.0 /)$.
Abstract: Six pseudohalide zinc(II) containing a variety of $\mathrm{N}$-donor auxiliary amines were structurally characterized. These include two mononuclear trigonal bipyramidal $\left[\mathrm{Zn}(\mathrm{NTB})\left(\mathrm{N}_{3}\right)\right] \mathrm{ClO}_{4} \cdot 1 / 2 \mathrm{H}_{2} \mathrm{O}$ (3) and [Zn(TPA)(NCS) $] \mathrm{ClO}_{4}$ (4), two distorted octahedral [Zn(1,8-damnph) $)_{2}$ (dca) $\left.)_{2}\right]$ (5) and [Zn(8$\left.\mathrm{amq})_{2}(\mathrm{dca})_{2}\right](6 \mathbf{a})$ as well as two $1 \mathrm{D}$ polymeric chains catena-[Zn(isq $\left.)_{2}\left(\mu_{1,5}-\mathrm{dca}\right)_{2}\right](7)$ and catena$\left[\mathrm{Zn}\left(N, N-\mathrm{Me}_{2} \mathrm{en}\right)_{2}\left(\mu_{1,5}\right.\right.$-dca) $] \mathrm{dca}(8)$, where NTB = tris(2-benzimidazolylmethyl)amine, TPA = tris $(2$ pyridylmethyl)amine, 1,8-damnph =1,8-diaminonaphthalene, 8 -amq $=8$-amino-quinoline, isq = isoquinoline (isq) and $\mathrm{N}, \mathrm{N}-\mathrm{Me}_{2} \mathrm{en}=\mathrm{N}, \mathrm{N}$-dimethylethylenediamine. In general, with the exception of 6 and 8, the complexes exhibited luminescence emission in $\mathrm{MeOH}$ associated with red shift of the emission maxima, and the strongest visible fluorescence peak was detected at $421 \mathrm{~nm}\left(\lambda_{\mathrm{ex}}=330 \mathrm{~nm}\right)$ in the case of Complex 5.

Keywords: zinc; dicyanamide; azide; isothiocyanate; X-ray; luminescence emission

\section{Introduction}

Group 12 of the periodic table and specifically zinc and cadmium, although they have common properties, exhibit different significant aspects. Both form very stable dipositive ions with an ionic radius of 0.88 and $1.09 \AA$ for $\mathrm{Zn}^{2+}$ and $\mathrm{Cd}^{2+}$, respectively. This of course results in different stabilities in their metal complexes, where in general, those of $\mathrm{Zn}$ (II) are more stable. While $\mathrm{Zn}^{2+}$ ions are essential for human life as they are involved in many catalytic enzymatic reactions and metalloenzymes as well as in zinc-protein complexes [1-5], the corresponding Cd(II) compounds are known to be highly toxic for humans and animals, and significantly pollutant to the environment [6]. Interestingly, regardless of the fact that $\mathrm{Zn}^{2+}$ and $\mathrm{Mg}^{2+}$ have almost identical ionic radii and higher $\mathrm{Mg}^{2+}$ concentrations in biological fluids, still $\mathrm{Zn}^{2+}$ cannot play the same role of $\mathrm{Mg}^{2+}$ in biological systems. Six-coordinate, octahedral [7-16] and tetrahedral, $T_{d}[7,8,17-23]$ as well as fivecoordinate (square pyramidal, SP, and trigonal bipyramid, TBP) [9-11,16,23] are the most common geometries in $\mathrm{Zn}$ (II) and Cd(II) compounds. However, seven-coordinate $\mathrm{Zn}$ (II) and Cd(II) compounds were also isolated and structurally characterized [13,24,25]. Moreover, three-coordinate species imposed by bulky organic co-ligand(s) were also reported [26,27].

In the presence of auxiliary ligands, the two metal ions $\mathrm{Zn}^{2+}$ and $\mathrm{Cd}^{2+}$ form extensive metal complexes with pseudo-halide ions $\left\{\mathrm{N}_{3}{ }^{-}, \mathrm{NCS}^{-}\right.$and dca (dicyanamide ion) $\}$with 
different degrees of nuclearity and polynuclear species as well as coordination polymers (CPs) with various architecture topologies [11-14,28-32]. The three anions $\mathrm{N}_{3}{ }^{-}, \mathrm{NCS}^{-}$ and dca are known to display a wide range of coordination modes through the two terminal bonding sites (end-to-end) and two sites of the same atom (end-on) as well as mixed bonding [8,9,11-14,25,28-35]. In addition, the corresponding dca ion provides the central amide nitrogen for linking metal ions [14,36,37]. These bonding modes have been previously addressed and summarized [14,32,38-41].

Another interesting feature in studying Zn(II) and Cd(II) complexes, particularly those derived from heterocyclic compounds, is their capabilities to furnish photoluminescence emission [15-17,19-23,25,34,35,42-44], which make them very attracting and fascinating compounds for serving as photochemical devices [43-48]. Two fluorescence tunings of $\mathrm{Zn}$ (II) complexes in terms of intensity and/or emission maximum, particularly fluorescence enhancement, chelation enhanced fluorescence $(\mathrm{CHEF})$ or reduction (fluorescence quenching), may occur [48-50]. These were correlated to the ability of the fluorophore coordinated ligand to form a $\pi$-contact with the metal cation [51]. In general, the $\mathrm{CHE}$ effect results from the stabilization of the excited state in poorly emissive ligands upon coordination with metal ions such as $\mathrm{Zn}^{2+}$, which tends to freeze the favorable re-emissive conformation resulting from the lowest excited energy states; from the ligand-centered charge transfer (LCT), mainly $\pi-\pi^{*}$ ligand to meatal charge transfer (LMCT) [52,53].

Herein, we investigate the interaction of $\mathrm{Zn}(\mathrm{II})$ with different pseudo-halides in the presence of flexible and rigid auxiliary ligands incorporating $N$-donor heterocyclic rings with possible ligand-centered charge transfer $\left(\pi-\pi^{*} \mathrm{LMCT}\right)$; a property that is required for observing luminescent emission. The structures of the ligands used in this study include 2-(ethyl-2-pyridyl)-2-methylquinolyl-methylamine (Meepmqa), tris(2benzimidazolylmethyl)amine (NTB), tris(2-pyridylmethyl)amine (TPA), 1,8-diaminonaphthalene (1,8-damnph), 8-amino-quinoline (8-amq) and isoquinoline (isq) as well as $N, N$ dimethylethylenediamine ( $\left.N, N-\mathrm{Me}_{2} \mathrm{en}\right)$, which lacks $\pi-\pi^{*}$ transition. The structures of these ligands are represented in Scheme 1. The luminescent emission properties of the complexes were also investigated. The synthesized pseudo-halido-zinc(II) complexes obtained from this study and other related literature will be structurally compared with those determined in the corresponding Cd(II) analogs containing the same pseudo-halides and auxiliary ligands.

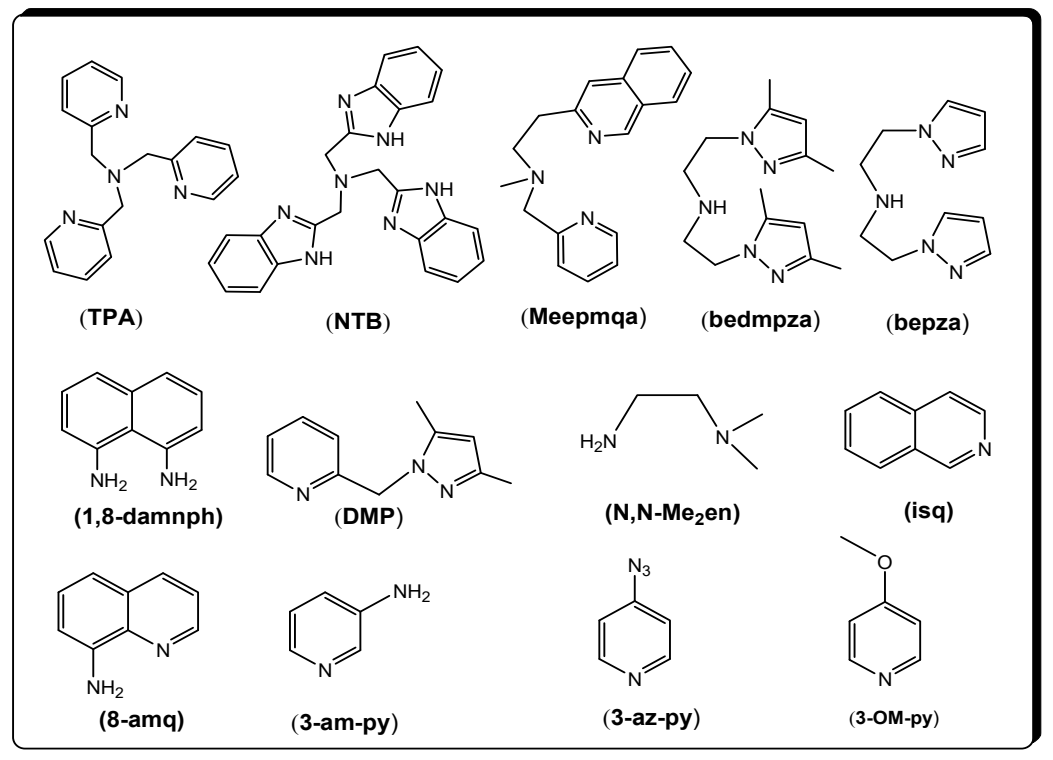

Scheme 1. N-Donor ligands used in this work and in other related studies. 


\section{Experimental Procedure}

\subsection{Materials and Physical Measurements}

8-Aminoquinoline, 1,8-diaminonaphthalene, isoquinoline, 1,2-diaminobenzene, 2,2', 2" nitrilotriacetic acid, $\mathrm{N}, \mathrm{N}$-dimethylethylenediamine and 2-picolylamine were purchased from TCI-America (Portland, OR, USA), whereas 2-[2-methylaminoethyl]-pyridine was purchased from Maybridge Co., Belgium. All other chemicals were reagent grade quality. The organic ligands 2-(ethyl-2-pyridyl)-2-methylquinolyl-methylamine (Meepmqa) [28], tris(2benzimidazolylmethyl)amine (NTB) [54] and tris(2-pyridylmethyl)amine (TPA) [55,56] were prepared according to published procedure. Infrared spectra were recorded on a Cary 630 (ATR-IR, $\mathrm{cm}^{-1}$ ) spectrometer. Electronic spectra were recorded using Agilent $8453 \mathrm{HP}$ diode UV-Vis spectrophotometer (Santa Clara, CA, USA). The fluorescence measurements were performed on Cary Eclipse fluorescence spectrophotometer (Agilent Technologies, Santa Clara, CA, USA). The Fluorescence Quantum Yield (FL QY) of all complexes in methanol was measured by an optically dilute (Optical Density $<0.2)$ relative method using 1,8 diaminonaphthalene as fluorescent standard of known QY in methanol. The molar conductivities of the complexes were performed in $\mathrm{CH}_{3} \mathrm{OH}$ solutions at room temperature using Mettler Toledo Seven Easy conductometer (Metler Toledo, Columbus, OH, USA) and calibration by the aid of $1413 \mu \mathrm{S} / \mathrm{cm}$ conductivity standard. The molar conductivity values were determined from $\Lambda_{\mathrm{M}}=\left(1.0 \times 10^{3} \mathrm{~K}\right) /[\mathrm{Zn}(\mathrm{II})]$, where $\mathrm{K}$ is the specific conductance and $[\mathrm{Zn}(\mathrm{II})]$ is the molar concentration of the complex. Elemental microanalyses were performed by the Atlantic Microlaboratory, Norcross, GA, USA.

Caution! Salts of perchlorate and azide as well as their metal complexes are potentially explosive and should be handled with great care and in small quantities.

\subsection{Preparation of the Compounds}

\subsection{1. $\left[\mathrm{Zn}\left(\right.\right.$ Meepmqa) $\left.\left(\mathrm{N}_{3}\right)_{2}\right](\mathbf{1})$}

To a solution containing $0.140 \mathrm{~g}$ of 2(ethyl-2-pyridyl)-2-methylquinolyl-methylamine, Meepmqa $(0.50 \mathrm{mmol})$ dissolved in $\mathrm{MeOH}(20 \mathrm{~mL}) \mathrm{Zn}\left(\mathrm{ClO}_{4}\right)_{2} \cdot 6 \mathrm{H}_{2} \mathrm{O}(0.190 \mathrm{~g}, 0.50 \mathrm{mmol})$ was added and this was followed by the addition of $\mathrm{NaN}_{3}(0.066 \mathrm{~g}, 0.5 \mathrm{mmol})$ dissolved in $\mathrm{H}_{2} \mathrm{O}(1-2 \mathrm{~mL})$. The resulting mixture was heated to boiling for $10 \mathrm{~min}$, filtered while hot and the resulting yellow solution was allowed to stand at room temperature. The yellow crystals, which were separated on the following day, were collected by filtration, washed with propan-2-ol and diethyl ether and air dried (yield: $0.132 \mathrm{~g}, 62 \%$ ). Anal. Calcd: $\mathrm{C}_{18} \mathrm{H}_{19} \mathrm{~N}_{9} \mathrm{Zn}(426.79 \mathrm{~g} / \mathrm{mol}): \mathrm{C}, 50.66 ; \mathrm{H}, 4.49 ; \mathrm{N}, 29.54 \%$. Found: $\mathrm{C}, 50.48 ; \mathrm{H}, 4.33 ; \mathrm{N}$, 29.72\%. IR bands (ATR, $\left.\mathrm{cm}^{-1}\right)$ : $3060(\mathrm{vw}), 2916,2874(\mathrm{vw}) v(\mathrm{C}-\mathrm{H}) ; 2055(\mathrm{vs}) v_{\mathrm{a}}\left(\mathrm{N}_{3}\right) ; 1600$ $(\mathrm{m}), 1571(\mathrm{~m}), 1510(\mathrm{~m}), 1432(\mathrm{~m}) \vee(\mathrm{C}=\mathrm{C}$ and $\mathrm{C}=\mathrm{N}), 752(\mathrm{~s}) . \mathrm{UV}\left(\mathrm{CH}_{3} \mathrm{OH}\right) \lambda_{\max }, \mathrm{nm}\left(\varepsilon_{\max }\right.$, $\left.\mathrm{M}^{-1} \mathrm{~cm}^{-1}\right): 237(\mathrm{sh}), 264\left(5.51 \times 10^{3}\right), 272\left(5.10 \times 10^{3}\right), 304\left(4.51 \times 10^{3}\right), 317\left(4.04 \times 10^{3}\right)$. Molar conductivity, $\Lambda_{\mathrm{M}}(\mathrm{MeOH})=11.3 \Omega^{-1} \cdot \mathrm{cm}^{2} \cdot \mathrm{mol}^{-1}$.

\subsection{2. [ $\mathrm{Zn}$ (Meepmqa)(dca) $] \mathrm{ClO}_{4} \cdot 1 / 2 \mathrm{H}_{2} \mathrm{O}$ (2)}

To a mixture containing $\mathrm{Zn}\left(\mathrm{ClO}_{4}\right)_{2} \cdot 6 \mathrm{H}_{2} \mathrm{O}(0.192 \mathrm{~g}, 0.5 \mathrm{mmol})$ and Meepmqa $(0.140 \mathrm{~g}$, $0.5 \mathrm{mmol}$ ) dissolved in $\mathrm{MeOH}(15 \mathrm{~mL})$, an aqueous solution $(5 \mathrm{~mL})$ of sodium dicyanamide $(0.090 \mathrm{~g}, 1 \mathrm{mmol})$ was added and the resulting faint yellow solution was heated for $10 \mathrm{~min}$ on a steam-bath, filtered through celite and then allowed to crystallize at room temperature. After $2 \mathrm{~h}$, the off-white crystalline compound that separated was collected by filtration, washed with propan-2-ol and $\mathrm{Et}_{2} \mathrm{O}$ and air dried (yield: $0.23 \mathrm{~g}, 89 \%$ ). Characterization: Anal. Calcd: $\mathrm{C}_{20} \mathrm{H}_{20} \mathrm{ClN}_{6} \mathrm{O}_{4.5} \mathrm{Zn}(517.25 \mathrm{~g} / \mathrm{mol}): \mathrm{C}, 46.44 ; \mathrm{H}, 3.90 ; \mathrm{N}, 16.25 \%$. Found: $\mathrm{C}$, 46.59, H, 3.82; N, 16.25\%. IR bands (ATR, $\left.\mathrm{cm}^{-1}\right)$ : $3527 v(\mathrm{O}-\mathrm{H}) ; 3130(\mathrm{vw}), 3076(\mathrm{vw}) v(\mathrm{C}-\mathrm{H})$; $2343(\mathrm{~m}), 2268(\mathrm{~m}), 2187(\mathrm{~s})(\mathrm{C} \equiv \mathrm{N}, \mathrm{dca}) ; 1604(\mathrm{~m}), 1514(\mathrm{w}), 1443(\mathrm{~m}), 1432(\mathrm{~m}), 1380(\mathrm{~m})$ $v(\mathrm{C}=\mathrm{C}$ and $\mathrm{C}=\mathrm{N}) ; 1076(\mathrm{vs}) \vee\left(\mathrm{Cl}-\mathrm{O}, \mathrm{ClO}_{4}^{-}\right)$. UV $(\mathrm{MeOH}) \lambda_{\max }, \mathrm{nm}\left(\varepsilon_{\max }, \mathrm{M}^{-1} \mathrm{~cm}^{-1}\right): \sim 240$ (sh), $264\left(5.04 \times 10^{3}\right), 272\left(4.40 \times 10^{3}\right), 304\left(4.32 \times 10^{3}\right), 317\left(4.28 \times 10^{3}\right)$. Molar conductivity, $\Lambda_{\mathrm{M}}(\mathrm{MeOH})=148 \Omega^{-1} \cdot \mathrm{cm}^{2} \cdot \mathrm{mol}^{-1}$. 


\subsection{3. $\left[\mathrm{Zn}(\mathrm{NTB})\left(\mathrm{N}_{3}\right)\right] \mathrm{ClO}_{4} \cdot 1 / 2 \mathrm{H}_{2} \mathrm{O}(3)$}

The complex was prepared using a similar procedure as that described for complex 1 except tris(2-benzimidazolylmethyl)amine (NTB) was used instead of TPA (yield: 72\%). Characterization: Anal. Calcd: $\mathrm{C}_{24} \mathrm{H}_{22} \mathrm{ClN}_{10} \mathrm{O}_{4.5} \mathrm{Zn}(623.34 \mathrm{~g} / \mathrm{mol}): \mathrm{C}, 46.24 ; \mathrm{H}, 3.56 ; \mathrm{N}$, 22.47\%. Found: C, 46.09; H, 3.61; N, 22.64\%. IR bands (ATR, $\left.\mathrm{cm}^{-1}\right)$ : $3612(\mathrm{vw}) ; 3266(\mathrm{w})$ $v(\mathrm{~N}-\mathrm{H}) ; 2062(\mathrm{vw}) ; 2904(\mathrm{vw}), 2850(\mathrm{w}) 2777(\mathrm{vw}) v(\mathrm{C}-\mathrm{H}) ; 2063(\mathrm{vs}) v\left(\mathrm{~N}_{3}{ }^{-}\right) ; 1625(\mathrm{~m}), 1596$ $(\mathrm{m}), 1540(\mathrm{~m}), 1492(\mathrm{~s}), 1472(\mathrm{~m}), 1455(\mathrm{~s}), 1389(\mathrm{~m}), 1343(\mathrm{~m}), 1317(\mathrm{~m}), 1277(\mathrm{~s}) \vee(\mathrm{C}=\mathrm{C}$ and $\mathrm{C}=\mathrm{N}) ; 1085$ (vs), 1041 (vs) v(Cl-O, $\left.\mathrm{ClO}_{4}^{-}\right)$; 960 (s), 915 (s), 844 (m) 754 (s), 742 (vs) 619 (vs). $\mathrm{UV}(\mathrm{MeOH}) \lambda_{\max }, \mathrm{nm}\left(\varepsilon_{\max }, \mathrm{M}^{-1} \mathrm{~cm}^{-1}\right): 209\left(3.68 \times 10^{4}\right), 242\left(1.22 \times 10^{4}\right), 279\left(2.04 \times 10^{4}\right)$. $\Lambda_{\mathrm{M}}(\mathrm{MeOH})=143 \Omega^{-1} \cdot \mathrm{cm}^{2} \cdot \mathrm{mol}^{-1}$.

\subsection{4. $[\mathrm{Zn}(\mathrm{TPA})(\mathrm{NCS})] \mathrm{ClO}_{4}(4)$}

Ammonium thiocyanate, $\mathrm{NH}_{4} \mathrm{NCS}(0.076 \mathrm{~g}, 1.0 \mathrm{mmol})$, was added to a mixture containing tris(2-aminomethylpyridine)amine, TPA $(0.146 \mathrm{~g}, 0.50 \mathrm{mmol})$ and $\mathrm{Zn}\left(\mathrm{ClO}_{4}\right)_{2} \cdot 6 \mathrm{H}_{2} \mathrm{O}$ $(0.190 \mathrm{~g}, 0.5 \mathrm{mmol})$ dissolved in $\mathrm{MeOH}(15 \mathrm{~mL})$. The resulting clear solution was heated for $10 \mathrm{~min}$ on a steam-bath, filtered and then allowed to crystallize at room temperature. After 3 days, the compound separated was collected by filtration and air dried (yield: $0.215 \mathrm{~g}$, $84 \%$ ). Colorless single crystals suitable for $\mathrm{X}$-ray analysis were obtained from dilute solution. Characterization: Anal. Calcd: $\mathrm{C}_{19} \mathrm{H}_{18} \mathrm{ClN}_{5} \mathrm{O}_{4} \mathrm{SZn}(513.29 \mathrm{~g} / \mathrm{mol}): \mathrm{C}, 44.46 ; \mathrm{H}, 3.53$; $\mathrm{N}, 13.64 \%$. Found: C, 43.98, H, 3.51; N, 14.13\%. IR bands (ATR, $\left.\mathrm{cm}^{-1}\right): 3075(\mathrm{vw}), 2914(\mathrm{vw})$ $v(\mathrm{C}-\mathrm{H}) ; 2070(\mathrm{vs})\left(\mathrm{C} \equiv \mathrm{N}, \mathrm{NCS}^{-}\right) ; 1610(\mathrm{~s}), 1574(\mathrm{~m}), 1483(\mathrm{~m}), 1439(\mathrm{~s}) \vee(\mathrm{C}=\mathrm{C}$ and $\mathrm{C}=\mathrm{N})$; 1078(vs), $1042(\mathrm{~s}), 1026(\mathrm{~s}) \vee\left(\mathrm{Cl}-\mathrm{O}, \mathrm{ClO}_{4}^{-}\right) ; 756(\mathrm{vs}) . \Lambda_{\mathrm{M}}(\mathrm{MeOH})=148 \Omega^{-1} \cdot \mathrm{cm}^{2} \cdot \mathrm{mol}^{-1}$.

\subsection{5. $\left[\mathrm{Zn}(1,8 \text {-damnph })_{2}(\mathrm{dca})_{2}\right](5)$}

The complex was prepared using a procedure similar to that described for 2, except two equivalents of 1,8-damnph were used instead of Meepmqa (yield: $0.203 \mathrm{~g}, 79 \%$ ). The same product was obtained with $\mathrm{Zn}\left(\mathrm{NO}_{3}\right)_{2} \cdot 6 \mathrm{H}_{2} \mathrm{O}$. Characterization: Anal. Calcd: $\mathrm{C}_{24} \mathrm{H}_{20} \mathrm{~N}_{10} \mathrm{Zn}(513.87 \mathrm{~g} / \mathrm{mol}): \mathrm{C}, 56.09 ; \mathrm{H}, 3.92 ; \mathrm{N}, 27.26 \%$. Found: $\mathrm{C}, 55.92, \mathrm{H}, 3.81 ; \mathrm{N}$, 27.01\%. IR bands (ATR, $\mathrm{cm}^{-1}$ ): $3246(\mathrm{~m}), 3148(\mathrm{~m}) v(\mathrm{~N}-\mathrm{H}) ; 3051(\mathrm{w}) v(\mathrm{C}-\mathrm{H}) ; 2260(\mathrm{~s}), 2222$ (s), $2156(\mathrm{vs})(\mathrm{C} \equiv \mathrm{N}, \mathrm{dca}) ; 1620(\mathrm{~m}), 1570(\mathrm{~m}), 1397(\mathrm{~m}), 1332(\mathrm{~s}), 1277(\mathrm{~m}) \vee(\mathrm{C}=\mathrm{C}$ and $\mathrm{C}=\mathrm{N})$; 1083 (vs), 998 (s), $911(\mathrm{~m}), 814(\mathrm{~s}), 757(\mathrm{vs}) . \mathrm{UV}(\mathrm{MeOH}) \lambda_{\max }, \mathrm{nm}\left(\varepsilon_{\max }, \mathrm{M}^{-1} \mathrm{~cm}^{-1}\right): 228$ $\left(2.82 \times 10^{4}\right), \sim 327\left(6.78 \times 10^{3}, \mathrm{~b}\right)$. Molar conductivity, $\Lambda_{\mathrm{M}}(\mathrm{MeOH})=9.6 \Omega^{-1} \cdot \mathrm{cm}^{2} \cdot \mathrm{mol}^{-1}$.

\subsection{6. $\left[\mathrm{Zn}(8 \text {-amq })_{2}(\mathrm{dca}) \mathrm{ClO}_{4}(\mathbf{6})\right.$}

The complex was prepared using a similar procedure as that described for complex 1 except 8-amq was used instead of Meepmqa (yield: $\sim 67 \%$ ). Characterization: Anal. Calcd: $\mathrm{C}_{20} \mathrm{H}_{16} \mathrm{ClN}_{7} \mathrm{Zn}(519.23 \mathrm{~g} / \mathrm{mol}): \mathrm{C}, 46.26 ; \mathrm{H}, 3.11 ; \mathrm{N}, 18.88 \%$. Found: $\mathrm{C}, 46.08, \mathrm{H}, 2.77 ; \mathrm{N}$, 20.83\%. IR bands (ATR, $\left.\mathrm{cm}^{-1}\right)$ : $3248(\mathrm{~m}), 3128(\mathrm{~m}) v(\mathrm{~N}-\mathrm{H}) ; 3075 v(\mathrm{C}-\mathrm{H}) ; 2285(\mathrm{~s}), 2235$

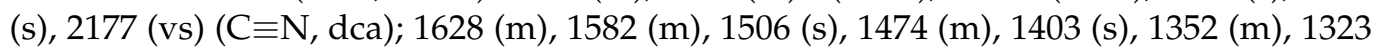
(s) $v(\mathrm{C}=\mathrm{C}$ and $\mathrm{C}=\mathrm{N}) ; 1070(\mathrm{vs}), 1029(\mathrm{vs}) \vee\left(\mathrm{Cl}-\mathrm{O}, \mathrm{ClO}_{4}^{-}\right) ; 827(\mathrm{~s}), 787(\mathrm{~s}), 764(\mathrm{~m}) 717(\mathrm{~s})$. $\mathrm{UV}(\mathrm{MeOH}) \lambda_{\max }, \mathrm{nm}\left(\varepsilon_{\max }, \mathrm{M}^{-1} \mathrm{~cm}^{-1}\right): 241\left(2.78 \times 10^{4}\right), 265(\mathrm{sh}), 336\left(4.74 \times 10^{3}\right)$. Molar conductivity, $\Lambda_{\mathrm{M}}(\mathrm{MeOH})=147 \Omega^{-1} \cdot \mathrm{cm}^{2} \cdot \mathrm{mol}^{-1}$.

\subsubsection{Catena- $\left[\mathrm{Zn}(\mathrm{isq})_{2}\left(\mu_{1,5} \text {-dca }\right)_{2}\right]$ (7)}

The complex was prepared using a procedure similar to that described for 2, except two equivalents of isoquinoline (isq) were used instead of Meepmqa (yield: 77\%). Characterization: Anal. Calcd: $\mathrm{C}_{22} \mathrm{H}_{14} \mathrm{~N}_{8} \mathrm{Zn}(455.79 \mathrm{~g} / \mathrm{mol})$ : C, 57.97; $\mathrm{H}, 3.10 ; \mathrm{N}, 24.58 \%$. Found: C, 58.27, H, 3.21; N, 24.59\%. IR bands (ATR, $\mathrm{cm}^{-1}$ ): 3075 (w) $v(\mathrm{C}-\mathrm{H}) ; 2290$ (s), 2234 (s), 2169

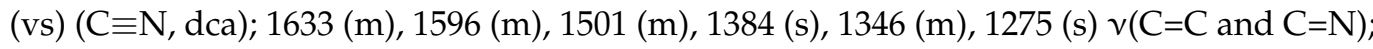
1042 (s), 1018 (m) 952 (m), 930 (s), 863 (m), 819 (vs), 773 (s) 741 (vs). UV (MeOH, saturated solution) $\lambda_{\max }, \mathrm{nm}: 210$ (sh), 260, 268, 280, 306, 319. 


\subsubsection{Catena- $\left[\mathrm{Zn}\left(\mathrm{N}, \mathrm{N}-\mathrm{Me}_{2} \mathrm{en}\right)_{2}\left(\mu_{1,5}\right.\right.$-dca $\left.)\right] \mathrm{dca}(8)$}

The complex was prepared using a procedure similar to that described for 2, except two equivalents of $\mathrm{N}, \mathrm{N}$-dimethylethylenediamine $\left(\mathrm{N}, \mathrm{N}-\mathrm{Me}_{2} \mathrm{en}\right)$ were used instead of Meepmqa (yield: $68 \%$ ). Characterization: Anal. Calcd: $\mathrm{C}_{12} \mathrm{H}_{24} \mathrm{~N}_{10} \mathrm{Zn}(455.79 \mathrm{~g} / \mathrm{mol}): \mathrm{C}, 38.56 ; \mathrm{H}$, 6.47; N, 37.47\%. Found: C, 38.45, H, 6.28; N, 37.59\%. IR bands (ATR, $\left.\mathrm{cm}^{-1}\right): 3295(\mathrm{w})$, $3249(\mathrm{w}) v(\mathrm{~N}-\mathrm{H}) ; 3167(\mathrm{w}), 2967(\mathrm{vw}), 2897(\mathrm{vw}) v(\mathrm{C}-\mathrm{H}) ; 2318(\mathrm{~m}), 2284(\mathrm{~m}), 2261(\mathrm{~m})$,

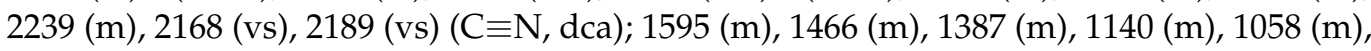
$1006(\mathrm{~m}), 930(\mathrm{~m}), 878(\mathrm{~m}), 283(\mathrm{~m}), 657(\mathrm{~m}) . \mathrm{UV}\left(\mathrm{MeOH}\right.$, saturated solution) $\lambda_{\max }, \mathrm{nm}$ : $\sim 243\left(1.00 \times 10^{4}\right), 265(\mathrm{sh}), 271\left(1.19 \times 10^{4}\right), 278\left(9.67 \times 10^{3}\right)$. Molar conductivity, $\Lambda_{\mathrm{M}}$ $(\mathrm{MeOH})=141 \Omega^{-1} \cdot \mathrm{cm}^{2} \cdot \mathrm{mol}^{-1}$.

\subsection{X-ray Crystal Structure Analysis}

The X-ray single-crystal data of the six title compounds were collected on a BrukerAXS APEX II CCD diffractometer (Bruker AXS, Karlsruhe, Germany) at 100(2) K. The crystallographic data, conditions retained for the intensity data collection and some features of the structure refinements are listed in Table 1. Data collections were performed with Mo-K $\alpha$ radiation $(\lambda=0.71073 \AA)$; data processing, Lorentz-polarization and absorption corrections were performed using the APEX and SADABS computer programs $[57,58]$. The structures were solved by direct methods and refined by full-matrix least-squares methods on $\mathrm{F}^{2}$, using the SHELX program library [59-61]. All non-hydrogen atoms were refined anisotropically. The hydrogen atoms were located from difference Fourier maps, assigned with isotropic displacement factors. Geometrical constraints (HFIX) were applied only for $\mathrm{H}$ atoms bonded to $\mathrm{C}$ atoms. Further programs used: Mercury and PLATON [62,63].

Table 1. Crystallographic data and processing parameters of 3, 4, 5, 6a, 7 and 8 .

\begin{tabular}{|c|c|c|c|}
\hline Compound & 3 & 4 & 5 \\
\hline Empirical formula & $\mathrm{C}_{48} \mathrm{H}_{44} \mathrm{Cl}_{2} \mathrm{~N}_{20} \mathrm{O}_{9} \mathrm{Zn}_{2}$ & $\mathrm{C}_{19} \mathrm{H}_{18} \mathrm{ClN}_{5} \mathrm{O}_{4} \mathrm{SZn}$ & $\mathrm{C}_{24} \mathrm{H}_{20} \mathrm{~N}_{10} \mathrm{Zn}$ \\
\hline Formula mass & 1246.71 & 513.28 & 513.87 \\
\hline System & Triclinic & Monoclinic & Monoclinic \\
\hline Space group & $\mathrm{P}-1$ & $\mathrm{P} 2{ }_{1} / \mathrm{c}$ & $\mathrm{P} 2_{1} / \mathrm{n}$ \\
\hline $\mathrm{a}(\AA)$ & $13.7520(9)$ & $15.2869(9)$ & $7.4176(4)$ \\
\hline$b(\AA)$ & $13.8644(8)$ & $9.6319(5)$ & $11.2397(6)$ \\
\hline$c(\AA)$ & $17.3919(10)$ & $14.7015(9)$ & $13.3287(6)$ \\
\hline$\alpha\left(^{\circ}\right)$ & $99.093(3)$ & 90 & 90 \\
\hline$\beta\left(^{\circ}\right)$ & $102.308(3)$ & 91.591(4) & $98.738(3)$ \\
\hline$\gamma\left({ }^{\circ}\right)$ & $119.270(2)$ & 90 & 90 \\
\hline $\mathrm{V}\left(\AA^{3}\right)$ & $2689.0(3)$ & $2163.8(2)$ & 1098.34(10) \\
\hline Z & 2 & 4 & 2 \\
\hline $\mathrm{D}_{\text {calc }}\left(\mathrm{Mg} / \mathrm{m}^{3}\right)$ & 1.540 & 1.576 & 1.554 \\
\hline$\theta \max \left({ }^{\circ}\right)$ & 27.544 & 28.782 & 33.204 \\
\hline Data collected & 24602 & 36586 & 49264 \\
\hline Unique refl./ $\mathrm{R}_{\mathrm{int}}$ & $12326 / 0.0642$ & $5570 / 0.0853$ & $4201 / 0.1122$ \\
\hline Parameters/Restraints & $725 / 140$ & $280 / 0$ & $176 / 0$ \\
\hline Goodness-of-Fit on $\mathrm{F}^{2}$ & 1.081 & 1.051 & 1.023 \\
\hline R1/wR2 (all data) & $0.0897 / 0.2605$ & $0.0520 / 0.1274$ & $0.0392 / 0.0826$ \\
\hline Residual extrema $\left(\mathrm{e} / \AA^{3}\right)$ & $3.202 /-2.305$ & $1.97 /-0.73$ & $0.59 /-0.55$ \\
\hline
\end{tabular}


Table 1. Cont.

\begin{tabular}{|c|c|c|c|}
\hline Compound & $6 a$ & 7 & 8 \\
\hline Empirical formula & $\mathrm{C}_{22} \mathrm{H}_{16} \mathrm{~N}_{10} \mathrm{Zn}$ & $\mathrm{C}_{22} \mathrm{H}_{14} \mathrm{~N}_{8} \mathrm{Zn}$ & $\mathrm{C}_{36} \mathrm{H}_{72} \mathrm{~N}_{30} \mathrm{Zn}_{3}$ \\
\hline Formula mass & 485.84 & 455.78 & 1121.34 \\
\hline System & Monoclinic & Triclinic & Monoclinic \\
\hline Space group & $\mathrm{P} 2{ }_{1} / \mathrm{n}$ & $\mathrm{P}-1$ & $\mathrm{C} \mathrm{m}$ \\
\hline a $(\AA)$ & $8.8263(3)$ & $7.406(3)$ & $13.4600(13)$ \\
\hline$b(\AA)$ & $7.2601(3)$ & $10.549(4)$ & $26.939(3)$ \\
\hline$c(\AA)$ & $16.0965(6)$ & $13.314(5)$ & $7.4731(7)$ \\
\hline$\alpha\left({ }^{\circ}\right)$ & 90 & $102.690(14)$ & 90 \\
\hline$\beta\left(^{\circ}\right)$ & $94.614(2)$ & $90.274(17)$ & $109.599(6)$ \\
\hline$\gamma\left({ }^{\circ}\right)$ & 90 & $110.278(16)$ & 90 \\
\hline $\mathrm{V}\left(\AA^{3}\right)$ & $1028.12(7)$ & $948.1(6)$ & $2522.8(5)$ \\
\hline Z & 2 & 2 & 2 \\
\hline $\mathrm{D}_{\text {calc }}\left(\mathrm{Mg} / \mathrm{m}^{3}\right)$ & 1.569 & 1.596 & 1.459 \\
\hline$\theta \max \left({ }^{\circ}\right)$ & 33.160 & 33.282 & 30.104 \\
\hline Data collected & 101990 & 76319 & 38697 \\
\hline Unique refl./ $R_{\text {int }}$ & $3932 / 0.0740$ & $7224 / 0.0762$ & $7333 / 0.0436$ \\
\hline Parameters/Restraints & $159 / 0$ & $283 / 0$ & $364 / 50$ \\
\hline Goodness-of-Fit on $\mathrm{F}^{2}$ & 1.074 & 1.104 & 1.038 \\
\hline R1/wR2 (all data) & $0.0282 / 0.0745$ & $0.0379 / 0.0899$ & $0.0253 / 0.0637$ \\
\hline Residual extrema $\left(\mathrm{e} / \AA^{3}\right)$ & $0.49 /-0.44$ & $0.60 /-0.70$ & $0.72 /-0.35$ \\
\hline
\end{tabular}

\section{Results and Discussion}

\subsection{Synthetic Aspects}

The interaction of a methanolic solution of $\mathrm{Zn}\left(\mathrm{NO}_{3}\right)_{2} \cdot 6 \mathrm{H}_{2} \mathrm{O}$ or $\mathrm{Zn}\left(\mathrm{ClO}_{4}\right)_{2} \cdot 6 \mathrm{H}_{2} \mathrm{O}$ and mono- or bidentate $\mathrm{N}$-donor ligands (L) with an aqueous solution containing the pseudohalides $\mathrm{NaN}_{3}, \mathrm{NH}_{4} \mathrm{NCS}$ or Nadca in the stoichiometric ratio 1:1:2 afforded only the corresponding di-pseudohalido compounds, $\left[\mathrm{Zn}(\mathrm{L})_{2}(\mathrm{X})_{2}\right]\{\mathrm{L}=1,8$-damnph, $\mathrm{X}=\mathrm{dca}(5) ; \mathrm{L}=$ isq, $\mathrm{X}=\mathrm{dca}(7)\}$. A polymeric complex with a similar chemical formula, catena- $[\mathrm{Zn}(N, N-$ $\left.\mathrm{Me}_{2} \mathrm{en}\right)_{2}\left(\mu_{1,5}\right.$-dca]dca (8), was obtained from the reaction of $\mathrm{Zn}\left(\mathrm{NO}_{3}\right)_{2} \cdot 6 \mathrm{H}_{2} \mathrm{O}, N, N-\mathrm{Me}_{2}$ en and Nadca. On the other hand, under similar conditions the corresponding reaction of $\mathrm{Zn}\left(\mathrm{ClO}_{4}\right)_{2} \cdot 6 \mathrm{H}_{2} \mathrm{O}$ and 8 -amq ligand in the presence of Nadca resulted in the formation of a mixture of the major product $\left[\mathrm{Zn}(8-\mathrm{amq})_{2}(\mathrm{dca}) \mathrm{ClO}_{4}(6)\right.$ and a small amount of the structurally characterized monomeric compound $\left[\mathrm{Zn}(8-\mathrm{amq})_{2}(\mathrm{dca})_{2}\right](\mathbf{6 a})$. The elemental microanalysis was close to the proposed formula 6 (Anal. Calcd: $\mathrm{C}_{20} \mathrm{H}_{16} \mathrm{ClN}_{7} \mathrm{Zn}$ : C, 46.26; H, 3.11; N, 18.88\%. Found: C, 46.08, H, 2.77; N, 20.83\%), and the presence of the dca and perchlorate in 6 was confirmed by IR. The molar conductivity measurement of the compound agreed with the 1:1 electrolytic nature of the complex (see Section 2Experimental Procedure). However, in the case of the tridentate amine, Meepmqa and $\mathrm{Zn}\left(\mathrm{ClO}_{4}\right)_{2}$ five-coordinate $\left[\mathrm{Zn}(\right.$ Meepmqa $\left.)\left(\mathrm{N}_{3}\right)_{2}\right](\mathbf{1})$ and $[\mathrm{Zn}(\mathrm{Meepmqa})(\mathrm{dca})] \mathrm{ClO}_{4} \cdot 1 / 2 \mathrm{H}_{2} \mathrm{O}$ (2) complexes were isolated in the presence of aqueous $\mathrm{NaN}_{3}$ and Nadca solutions, respectively. When $\mathrm{Zn}\left(\mathrm{ClO}_{4}\right)_{2} \cdot 6 \mathrm{H}_{2} \mathrm{O}$ was employed with the tripod tetraamines (NTB, TPA) and the pseudohalide salts in the 1:1:2 molar ratio, the five-coordinate mono-pseudohalido perchlorate compounds $[\mathrm{Zn}(\mathrm{L})(\mathrm{X})] \mathrm{ClO}_{4}\left\{\mathrm{~L}=\mathrm{NTB}, \mathrm{X}=\mathrm{N}_{3}^{-}\right.$(3); $\mathrm{L}=\mathrm{TPA}, \mathrm{X}=\mathrm{NCS}^{-}$(4) $\}$ were the only products regardless of the excess pseudohalide salts used. Similar products, $\left[\mathrm{Zn}(\mathrm{NTB})\left(\mathrm{N}_{3}\right)\right] \mathrm{NO}_{3}\left(3 \mathrm{a}\right.$, Supplementary Materials (SM)) and $[\mathrm{Zn}(\mathrm{TPA})(\mathrm{NCS})] \mathrm{NO}_{3} \cdot 1 / 2 \mathrm{H}_{2} \mathrm{O}$ $(4 \mathbf{b}, \mathrm{SM})$, were obtained in the presence of the appropriate co-ligand and pseudohalide salt 
when zinc(II) nitrate was used instead of the perchlorate (see SM). Whenever the solubility of the complexes in $\mathrm{CH}_{3} \mathrm{OH}$ permits, the molar conductivity values, $\Lambda_{\mathrm{M}}$ for 2-4, 6 and 8 , were found to be in the range $141-148 \Omega^{-1} \cdot \mathrm{cm}^{2} \cdot \mathrm{mol}^{-1}$, which are in complete agreement for their 1:1 electrolytic nature [64]. The non-electrolytic nature of 1 and 5 was also confirmed $\left(\Lambda_{\mathrm{M}}=11.3\right.$ and $9.6 \Omega^{-1} \cdot \mathrm{cm}^{2} \cdot \mathrm{mol}^{-1}$, respectively). The compounds were characterized by IR and UV spectroscopy as well as elemental microanalyses. The molecular structures of 3-5 and 6a-8 were determined by single crystal X-ray crystallography.

\subsection{IR Spectra of the Complexes}

The infra-red spectra of the complexes under investigation display general characteristic features for each category of the pseudohalides. The azido compounds $\mathbf{1}$ and $\mathbf{3}$ exhibit their strong vibrational frequencies at 2055 and $2063 \mathrm{~cm}^{-1}$, respectively, due to the asymmetric stretching vibrations, $v_{a}$, of the azido ligands $[8,9,11,28,29,31,34,35,38-40]$. The isothiocyanato complex 4 reveals a strong band at $2070 \mathrm{~cm}^{-1}$, which is inconsistent with N-NCS bonding; the S-NCS bonding, in general, absorbs at a frequency value slightly greater than $2100 \mathrm{~cm}^{-1}[12,33,40,65]$. The IR spectra of the dicyanamido complexes $5, \mathbf{6}$ and 7 display three medium-strong intense bands over the 2290-2260, 2240-2220 and 2160$2180 \mathrm{~cm}^{-1}$ regions, whereas the corresponding bands were located at higher values for $\left[\mathrm{Zn}(\right.$ Meepa)(dca) $] \mathrm{ClO}_{4} \cdot 1 / 2 \mathrm{H}_{2} \mathrm{O}(2)$. These vibrational bands are attributed to $v_{\mathrm{as}}(\mathrm{C} \equiv \mathrm{N})$ and $v_{\mathrm{s}}+v_{\mathrm{as}}(\mathrm{C} \equiv \mathrm{N})$ and $v_{\mathrm{s}}(\mathrm{C} \equiv \mathrm{N})$, respectively $[14,25,30,32,36,41,66]$. The observed dca bands in catena-[Zn(N,N-Me $\left.{ }_{2} \mathrm{en}\right)_{2}\left(\mu_{1,5}\right.$-dca $\left.)\right] d c a(8)$ were further split into 2318, 2284, 2261, 2239, 2168 , and $2189 \mathrm{~cm}^{-1}$ as expected because of the presence of dca anions in two different bonding modes. The perchlorate compound 2 reveals its strong vibrational frequency value due to the $\mathrm{Cl}-\mathrm{O}$ stretching of the counter $\mathrm{ClO}_{4}{ }^{-}$ion at $1073 \mathrm{~cm}^{-1}$. The split of this band into two in $\left[\mathrm{Zn}(8-\mathrm{amq})_{2}(\mathrm{dca}) \mathrm{ClO}_{4}(6)\right.$ or three in $[\mathrm{Zn}(\mathrm{TPA})(\mathrm{NCS})] \mathrm{ClO}_{4}$ (4) (see Experimental Procedure section) may result from reducing the local symmetry of the $\mathrm{ClO}_{4}{ }^{-}$ion from $T_{d}$ to $\mathrm{C}_{3 \mathrm{v}}$ or $\mathrm{C}_{2 \mathrm{v}}$.

\subsection{Description of the Structures}

\subsection{1. $\left[\mathrm{Zn}(\mathrm{NTB})\left(\mathrm{N}_{3}\right)\right] \mathrm{ClO}_{4} \cdot 1 / 2 \mathrm{H}_{2} \mathrm{O}(3)$ and $\left[\mathrm{Zn}(\mathrm{TPA})(\mathrm{NCS}) \mathrm{ClO}_{4}\right.$ (4)}

The asymmetric unit of compound 3 contains two monomeric $\left[\mathrm{Zn}(\mathrm{NTB})\left(\mathrm{N}_{3}\right)\right]^{+}$complex cations, one ordered and one disordered perchlorate counter anion and a noncoordinated water molecule, whereas compound 4 crystallizes with one monomeric $[\mathrm{Zn}(\mathrm{TPA})(\mathrm{NCS})]^{+}$complex cation and one perchlorate counter anion in the asymmetric unit. In 3, each $\mathrm{Zn}^{2+}$ center is penta-coordinated by four $N$-donor atoms of the tripod NTB molecule and $N$-donor of the terminal azide anion, and in 4 by four $N$-donor atoms of the tripod TPA molecule and $\mathrm{N}$-coordinated $\mathrm{NCS}^{-}$anion (Figure 1 and selected bond parameters are shown in Table S1). The $\mathrm{ZnN}_{5}$ polyhedra show distorted trigonal bipyramidal (TBP) geometry with a $\tau$ value of 0.87 [0.83] for $\mathrm{Zn} 1$ [Zn2] polyhedron in 3, and 0.85 in the case of 4 ( $\tau$ value refers to 0 for ideal square pyramid SP and 1 for ideal TBP geometry) [67]. The equatorial positions occupied by the coordinated $N$-donor of the three arms of tripod ligands with $\mathrm{Zn}-\mathrm{N}(\mathrm{eq})$ bond distances are in the range from 2.002(5) to 2.079(3) $\AA$, and $\mathrm{N}-(\mathrm{eq})-\mathrm{Zn}-\mathrm{N}(\mathrm{eq})$ angles from $106.1(2)$ to $124.32(11)^{\circ}$. One axial position is occupied by the coordinated $\mathrm{N}$-donor atom of the pseudohalide anion with a $\mathrm{Zn}-\mathrm{N}$ (azide) bond distance of 2.020(5) [2.019(5)] $\AA$ in 3 and a Zn-N(NCS) bond distance of 2.006(3) $\AA$ in 4. The other axial position is occupied by the central amine $N$-donor of the tripod NTB (in 3) or TPA (in 4) ligand molecule, respectively, with a longer $\mathrm{Zn}-\mathrm{N}$ (amine) bond length of 2.491(5) [2.489(5)] $\AA$ in 3 and 2.261(3) $\AA$ in 4. The axial N-Zn-N bond angle is $174.4(2)^{\circ}\left[173.0(2)^{\circ}\right]$ in 3 and $175.26(12)^{\circ}$ in 4 . The terminal azide groups are asymmetric with a mean difference of the $\mathrm{N}-\mathrm{N}$ bond lengths of $0.034 \AA$. The $\mathrm{Zn}-\mathrm{N}-\mathrm{N}$ and $\mathrm{N}-\mathrm{N}-\mathrm{N}$ bond angles in 3 are $119.9(4)^{\circ}$ $\left[120.7(4)^{\circ}\right]$ and $178.5(6)^{\circ}\left[177.6(7)^{\circ}\right]$, whereas in 4 the $\mathrm{Zn}-\mathrm{N}-\mathrm{C}$ and $\mathrm{N}-\mathrm{C}-\mathrm{S}$ bond angles are $154.3(3)^{\circ}$ and $178.8(3)^{\circ}$. In 3 , the building blocks are interlinked by hydrogen bonds of type $\mathrm{O}-\mathrm{H} \cdots \mathrm{O}, \mathrm{N}-\mathrm{H} \cdots \mathrm{O}$ and $\mathrm{N}-\mathrm{H} \cdots \mathrm{N}$, whereas in 4 no classical hydrogen bonds are observed (Figures S1 and S2, Table S2). 

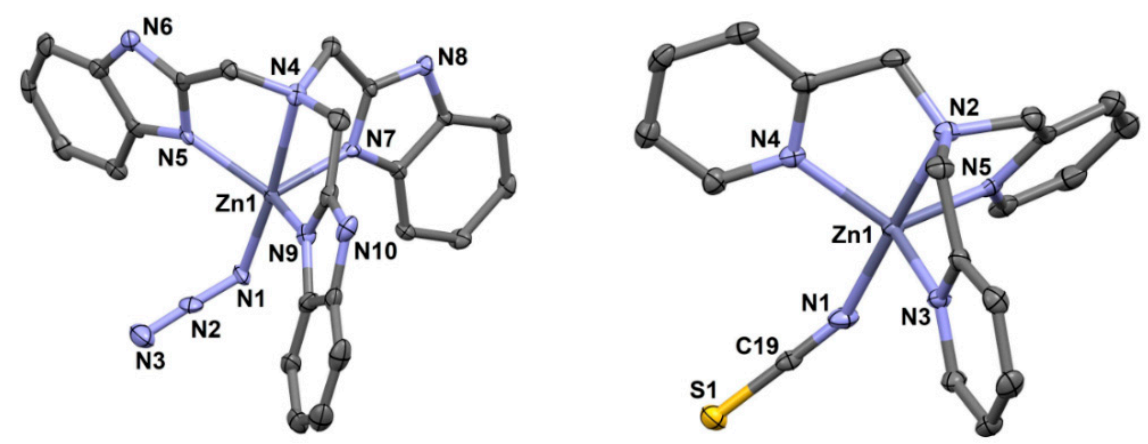

Figure 1. Complex cations of $\mathrm{Zn} 1$ centers in structures of 3 (left) and of 4 (right).

\subsection{2. $\left[\mathrm{Zn}(1,8-\text { damnph })_{2}(\mathrm{dca})_{2}\right](5)$ and $\left[\mathrm{Zn}(8-\mathrm{amq})_{2}(\mathrm{dca})_{2}\right](\mathbf{6 a})$}

In the centrosymmetric mononuclear complexes $\left[\mathrm{Zn}(1,8 \text {-damnph })_{2}(\mathrm{dca})_{2}\right](5)$ and $\left[\mathrm{Zn}(8-\mathrm{amq})_{2}(\mathrm{dca})_{2}\right](\mathbf{6 a})$ (Figure 2 and selected bond parameters are shown in Table S1), the $\mathrm{Zn}$ (II) centers form axially elongated octahedra by the ligation of four $\mathrm{N}$-donor atoms of two trans-coordinated 1,8-diaminonaphthalene (5) and 8-aminoquinoline (6a) molecules and of two terminal dicyanamide ligands. The axial $\mathrm{Zn} 1-\mathrm{N}(\mathrm{dca})$ bond distances are 2.2179(14) and 2.2051(11) $\AA$, whereas the equatorial $\mathrm{Zn1}-\mathrm{N}$ bond distances are in the range from 2.1199(15) to $2.1620(14) \AA$, respectively. The N1-Zn1-N2 bite angle is $80.25(6)$ and $78.94(4)^{\circ}$ for the six-membered chelate ring in $\mathbf{5}$ and the five-membered chelate ring in $\mathbf{6 a}$, respectively, whereas the other $\mathrm{N}-\mathrm{Zn}-\mathrm{N}$ cisoid bond angles deviate less than $2.8^{\circ}$ in $\mathbf{5}$ and $5.9^{\circ}$ in $\mathbf{6 a}$ from a rectangular angle. The naphthalene-rings in 5 , as well as the quinoline rings in $\mathbf{6 a}$, are inclined by 52.2 and $22.3^{\circ}$ to their mean equatorial $\mathrm{ZnN}_{4}$ plane. The terminal dca anions have the following bond parameters: $\mathrm{Zn}-\mathrm{N}-\mathrm{C}: 161.72(14)$ and $147.31(10)^{\circ} ; \mathrm{N}-\mathrm{C}-\mathrm{N}$ : from 171.69(14) to $173.71(14)^{\circ}$; $\mathrm{C}-\mathrm{N}-\mathrm{C}: 121.66(16)$ and $122.26(12)^{\circ}$; $\mathrm{C}-\mathrm{N}($ nitrile): from $1.155(2)$ to 1.1648(18) $\AA$; N-C(amine): from 1.3042(17) to 1.321(2) $\AA$. Hydrogen bonds of type $\mathrm{N}-\mathrm{H} \cdot \mathrm{N}$ to adjacent non-coordinated N5 acceptor atoms of dca anions form a supramolecular 2D system in 6a, whereas N4 and N5 atoms of neighboring dca anions act as acceptors for hydrogen bonds of type $\mathrm{N}-\mathrm{H} \cdots \mathrm{N}$ to generate a supramolecular 3D network structure with bcu topology in 5 (Table S2, Figures S3 and S4) [61-63].
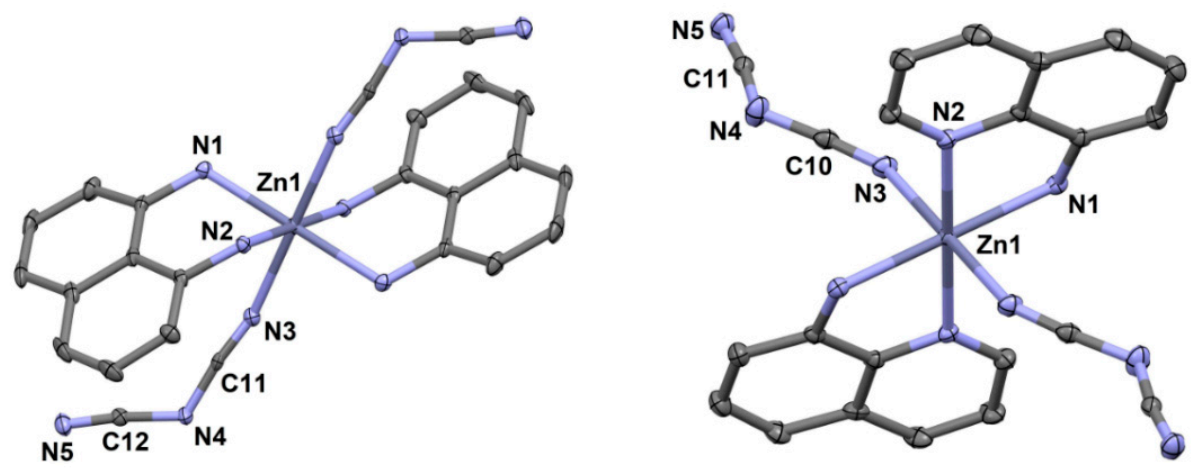

Figure 2. Coordination figures of 5 (left) and of $6 \mathbf{a}$ (right).

\subsubsection{Catena-[Zn(isq $\left.)_{2}\left(\mu_{1,5} \text {-dca }\right)_{2}\right](7)$ and Catena-[Zn(N,N-Me $\left.{ }_{2} \mathrm{en}\right)\left(\mu_{1,5}\right.$-dca) $] \mathrm{dca}(8)$}

The common feature of $\mathbf{7}$ and $\mathbf{8}$ is 1D polymeric chains (Figures 3 and 4 and bond parameters are shown in Table S1). In 7, neutral chains of catena-[Zn(isq $\left.)_{2}\left(\mu_{1,5}-\mathrm{dca}\right)_{2}\right]$ are formed via bis $\mu_{1,5}-d c a$ bridging ligands, which connect the $\mathrm{Zn}$ (II) metal centers along the $a$-axis of the unit cell. Each $\mathrm{ZnN}_{6}$ octahedron is completed by two terminal isoquinoline molecules in trans disposition. The $\mathrm{Zn}-\mathrm{N}$ bond distances vary from 2.1369(17) to 2.1735(17) $\AA$ and $\mathrm{N}-\mathrm{Zn}-\mathrm{N}$ bond angles deviate less than $0.60^{\circ}$ from ideal octahedral geometry. The parallel stacking of the isoquinoline molecules is stabilized by the formation of $\pi \cdots \pi$ ring $\cdots$ ring interactions (Table S3,Figure S5). The cationic chains in $\mathbf{8}$ are formed via single 
$\mu_{1,5}-d c a$ bridging ligands, which connect the metal centers in an alternate [Zn1 $\left.\cdots \mathrm{Zn} 1 \cdots \mathrm{Zn} 2\right]$ sequence along the $b$-axis of the unit cell. Each distorted $\mathrm{ZnN}_{6}$ octahedron is completed by four $\mathrm{N}$-donors of two chelating $\mathrm{N}, \mathrm{N}-\mathrm{Me}_{2}$ en molecules in trans disposition. The $\mathrm{Zn}-\mathrm{N}$ bond distances vary from 2.063(4) to 2.278(3) $\AA$ and $\mathrm{N}-\mathrm{Zn}-\mathrm{N}$ bond angles deviate up to $7.5^{\circ}$ from ideal octahedral geometry. Hydrogen bonds of type $\mathrm{N}-\mathrm{H} \cdots \mathrm{N}$ are formed between $\mathrm{N}, \mathrm{N}-\mathrm{Me}_{2}$ en and dca counter anions, which are arranged parallel to the $\mu_{1,5}$-dca bridging ligands, to generate a supramolecular 2D system oriented along the $a$-and $b$-axis of the unit cell (Table S2, Figure S6). The dca anions in 7 and 8 have the following bond parameters: $\mathrm{Zn}-\mathrm{N}-\mathrm{C}$ : from $148.80(15)$ to $168.49(16)^{\circ} ; \mathrm{N}-\mathrm{C}-\mathrm{N}$ : from $170.5(4)$ to $175.1(2)^{\circ} ; \mathrm{C}-\mathrm{N}-\mathrm{C}$ : from 119.09(17) to $125.7(4)^{\circ} ; \mathrm{C}-\mathrm{N}$ (nitrile): from 1.144(4) to 117.0(5) $\AA$; $\mathrm{N}-\mathrm{C}$ (amine): from 1.296(4) to $1.313(2) \AA$. Partial two-fold disorder is observed for $\mathrm{N}, \mathrm{N}-\mathrm{Me}_{2}$ en molecules ligated to $\mathrm{Zn} 2$, which is located on the special position.

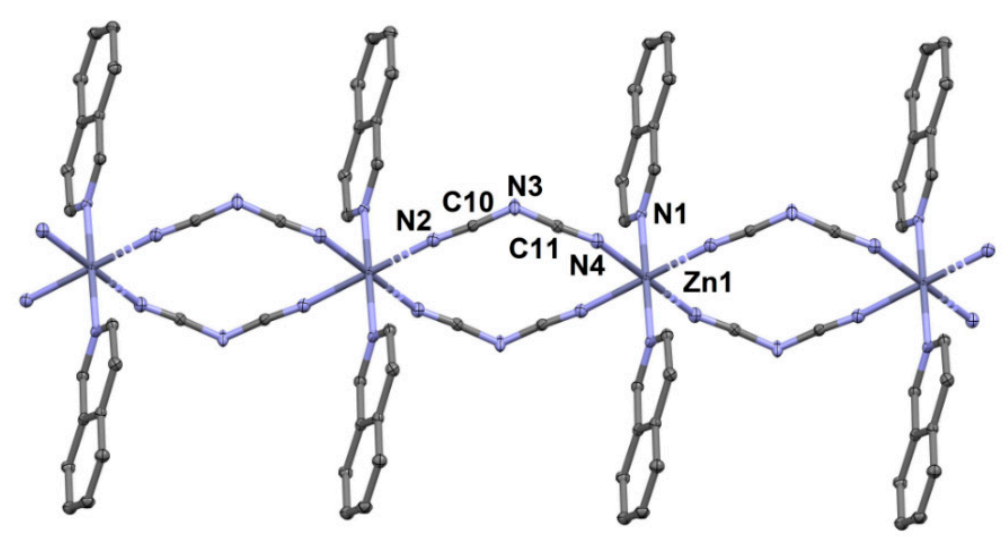

Figure 3. Polymeric chain of 7 .

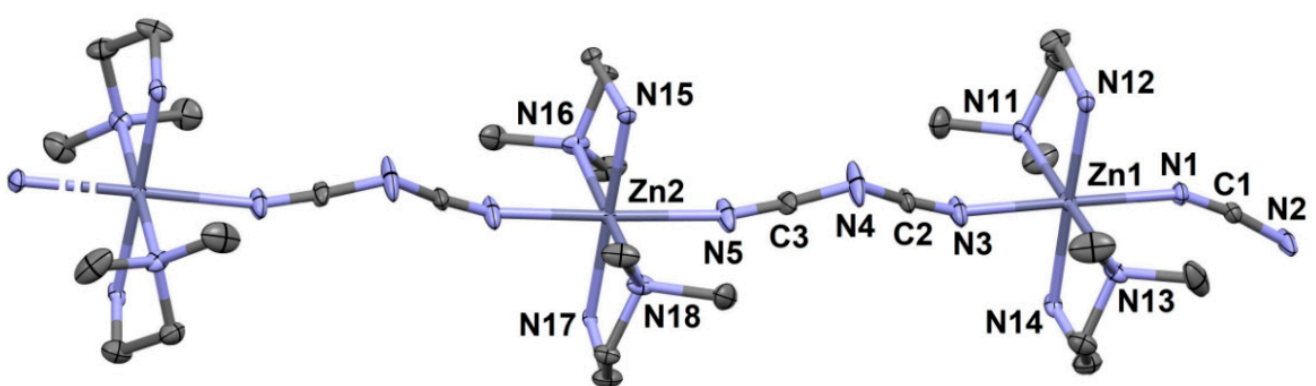

Figure 4. Polymeric cationic chain of 8. Only one orientation of disordered $N, N-\mathrm{Me}_{2}$ en groups around $\mathrm{Zn} 2$ is given for clarity.

\subsection{Structural Comparison between Zinc(II) Complexes and Cadmium(II) Analogs}

In this section, we are focusing on the $\mathrm{Zn}$ (II)-pseudohalide complexes and their corresponding structurally characterized $\mathrm{Cd}(\mathrm{II})$ analogs containing the same auxiliary ligands and pseudohalides. These compounds are collected in Table 2 for comparison. Inspection of the data in this table reveals that although the two metal ions can produce compounds with similar geometrical features and the same pseudohalide bonding modes (see entries 7-10, 12 and 13 and 20-25), still many other compounds show significant differences with respect to geometry, nuclearity and pseudohalide bonding modes (entries $1-5,9$ and 11 and 14-19). This behavior precludes any possibility of predicting the structure of any of the two complexes if one of them was determined. This could not only be attributed to the smaller ionic size of the $\mathrm{Zn}^{2+}$ ion but also to its hard Lewis acid nature in regard to the soft $\mathrm{Cd}^{2+}$ ion. 
Table 2. Structural parameters of pseudohalido-Zn(II) complexes and their Cd(II) analogs * .

\begin{tabular}{|c|c|c|c|c|c|}
\hline$\#$ & Zn(II) or Cd(II) Complex & Pseudoh. Bonding & Geom. & Dim./Nuc. & Ref. \\
\hline 1 & {$\left[\mathrm{Zn}(\mathrm{TPA})\left(\mathrm{N}_{3}\right)\right] \mathrm{ClO}_{4}(4 \mathrm{a})$} & monodentate $\mathrm{N}_{3}^{-}$ & TBP & mononuclear & [68] \\
\hline 2 & $\begin{array}{c}{\left[\mathrm{Cd}_{6}(\mathrm{TPA})_{4}\left(\mu_{1,1,3^{-}}\right.\right.} \\
\left.\left.\mathrm{N}_{3}\right)_{4}\left(\mu_{1,1} \mathrm{~N}_{3}\right)_{6}\right]\left(\mathrm{ClO}_{4}\right)_{2} \cdot 2 \mathrm{H}_{2} \mathrm{O}\end{array}$ & $\begin{array}{c}\mu_{1,1,3^{-}} \mathrm{N}_{3}^{-}, \mu_{1,1^{-}} \\
\mathrm{N}_{3}^{-}\end{array}$ & dist. $\mathrm{O}_{\mathrm{h}}$, and $\mathrm{PBP}$ & hexanuclear & [13] \\
\hline 3 & {$\left[\mathrm{Zn}(\mathrm{TPA})\left(\mathrm{N}_{3}\right)_{2}\right]$} & monodentate $\mathrm{N}_{3}^{-}$ & dist. $\mathrm{O}_{\mathrm{h}}$ & mononuclear & [68] \\
\hline 4 & catena-[Zn(N,N-Me $\left.{ }_{2} \mathrm{en}\right)_{2}\left(\mu_{1,5}\right.$-dca $\left.)\right] \mathrm{dca}(8)$ & $\mu_{1,5}$-dca & dist. $\mathrm{O}_{\mathrm{h}}$ & CPs,1D & This work \\
\hline 5 & catena- $\left[\mathrm{Cd}\left(\mathrm{N}, \mathrm{N}-\mathrm{Me}_{2} \mathrm{en}\right)\left(\mu_{1,5} \text {-dca }\right)_{2}\right]$ & $\mu_{1,5}$-dca & dist. $\mathrm{O}_{\mathrm{h}}$ & $\begin{array}{l}\text { CPs, } 1 \mathrm{D} \text { double } \\
\text { chains }\end{array}$ & [14] \\
\hline 6 & {$\left[\mathrm{Zn}(\mathrm{isq})_{2}(\mathrm{NCS})_{2}\right]$} & monodentate $\mathrm{NCS}^{-}$ & dist. $\mathrm{T}_{\mathrm{d}}$ & mononuclear & {$[69]$} \\
\hline 7 & trans-[Zn(isq) $\left.)_{4}(\mathrm{NCS})_{2}\right]$ & monodentate $\mathrm{NCS}^{-}$ & trans $-\mathrm{O}_{\mathrm{h}}$ & mononuclear & {$[69]$} \\
\hline 8 & trans-[Cd(isq) $\left.)_{4}(\mathrm{NCS})_{2}\right]$ & monodentate $\mathrm{NCS}^{-}$ & trans $-\mathrm{O}_{\mathrm{h}}$ & mononuclear & [69] \\
\hline 9 & cis-[Zn(8-amq $\left.)_{2}(\mathrm{NCS})_{2}\right]$ & monodentate $\mathrm{NCS}^{-}$ & cis- $\mathrm{O}_{\mathrm{h}}$ & mononuclear & {$[70]$} \\
\hline 10 & cis-[Cd(8-amq $\left.)_{2}(\mathrm{NCS})_{2}\right]$ & monodentate $\mathrm{NCS}^{-}$ & cis- $\mathrm{O}_{\mathrm{h}}$ & mononuclear & [34] \\
\hline 11 & catena- $\left[\mathrm{Cd}(8\right.$-amq $\left.)\left(\mu_{1,3}-\mathrm{NCS}\right)_{2}\right]$ & $\mu_{1,3}$-NCS $^{-}$ & dis. Oh & CPs, 1D & [71] \\
\hline 12 & trans-[Zn(1,8-damnph $\left.)_{2}(\mathrm{dca})_{2}\right](5)$ & monodentate dca & trans-Oh & mononuclear & This work \\
\hline 13 & trans-[Cd(1,8-damnph $\left.)_{2}(\mathrm{dca})_{2}\right]$ & monodentate dca & trans-Oh & mononuclear & {$[14]$} \\
\hline 14 & {$\left[\mathrm{Zn}(\right.$ bedmpza $)\left(\mathrm{N}_{3}\right) \mathrm{ClO}_{4}$} & monodentate $\mathrm{N}_{3}^{-}$ & dist. TBP & mononuclear & {$[11]$} \\
\hline 15 & {$\left[\mathrm{Cd}(\text { bedmpza })\left(\mu_{1,1}-\mathrm{N}_{3}\right)\left(\mathrm{N}_{3}\right)\right]_{2} \cdot 1.5 \mathrm{H}_{2} \mathrm{O}$} & $\begin{array}{c}\mu_{1,1}-\mathrm{N}_{3}^{-}, \\
\text {monodentate } \mathrm{N}_{3}^{-}\end{array}$ & dist. Oh & dinuclear & [11] \\
\hline 16 & [Zn(bepza)(NCS) $\left.{ }_{2}\right]$ & monodentate $\mathrm{NCS}^{-}$ & dist. TBP & monomer & {$[12]$} \\
\hline 17 & {$\left[\mathrm{Cd}_{2}(\text { bepza })_{2}\left(\mu_{1,3}-\mathrm{NCS}\right)_{2}(\mathrm{NCS})_{2}\right]$} & $\begin{array}{c}\mu_{1,3}-\mathrm{NCS}^{-} \\
\text {mono-dentate } \mathrm{NCS}^{-}\end{array}$ & dist. Oh & dinuclear & [12] \\
\hline 18 & {$\left[\mathrm{Zn}(\mathrm{DMP})\left(\mu_{1,1}-\mathrm{N}_{3}\right)\left(\mathrm{N}_{3}\right)\right]_{2}$} & $\mu_{1,1}-N_{3}^{-}$ & dist. TBP & dinuclear & [28] \\
\hline 19 & catena- $\left[\mathrm{Cd}(\mathrm{DMP})\left(\mu_{1,1}-\mathrm{N}_{3}\right)_{2}\right]$ & $\mu_{1,1^{-}}-\mathrm{N}_{3}^{-}$ & dist. Oh & CPs, 1D & [28] \\
\hline 20 & catena-[Zn(3-ampy $\left.)_{2}\left(\mu_{1,5} \text {-dca }\right)_{2}\right]$ & $\mu_{1,5}$-dca & dist. Oh & CPs, 3D & {$[30]$} \\
\hline 21 & catena- $\left[\mathrm{Cd}(3\right.$-ampy $)\left(\mu_{1,3}\right.$-dca $)\left(\mu_{1,5}\right.$-dca $\left.)\right]$ & $\mu_{1,5}$-dca, $\mu_{1,3}$-dca & dist. Oh & CPs, 3D & {$[30]$} \\
\hline 22 & catena- $\left[\mathrm{Zn}(4-\mathrm{OMP})_{2}\left(\mu_{1,5} \text {-dca }\right)_{2}\right]$ & $\mu_{1,5}$-dca & dist. Oh & CPs, 1D & {$[32]$} \\
\hline 23 & catena-[Cd(4-OMP $\left.)_{2}\left(\mu_{1,5} \text {-dca }\right)_{2}\right]$ & $\mu_{1,5}$-dca & dist. Oh & CPs, 1D & {$[32]$} \\
\hline 24 & catena- $\left[\mathrm{Zn}(4 \text {-azpy })_{2}\left(\mu_{1,1}-\mathrm{N}_{3}\right)\left(\mu_{1,3}-\mathrm{N}_{3}\right)\right]$ & $\mu_{1,1}-N_{3}^{-}, \mu_{1,3}-N_{3}^{-}$ & dist. Oh & CPs, 1D & {$[31]$} \\
\hline 25 & $\begin{array}{c}\text { catena- }\left[\mathrm{Cd}_{2}(4-\text { azpy })_{4}\left(\mu_{1,1^{-}}-\mathrm{N}_{3}\right)_{2}\left(\mu_{1,3^{-}}\right.\right. \\
\left.\left.\mathrm{N}_{3}\right)_{2}\right]\end{array}$ & $\mu_{1,1^{-}} \mathrm{N}_{3}^{-}, \mu_{1,3}-\mathrm{N}_{3}^{-}$ & dist. Oh & CPs, 1D & [31] \\
\hline
\end{tabular}

* Abbreviations: Pseudoh. $=$ pseudohalide anion, $\mathrm{CPs}=$ coordination polymer, $\mathrm{Dim}=$ dimensional, Nuc $=$ nuclearity, dist. $=$ distorted, $\mathrm{O}_{\mathrm{h}}=$ octahedral, $\mathrm{T}_{\mathrm{d}}=$ tetrahedral, $\mathrm{SP}=$ square pyramidal, $\mathrm{PBP}=$ pentagonal bipyramid, TPA = Tris(2-pyridylmethy)amine, $\mathrm{N}, \mathrm{N}-$ $\mathrm{Me}_{2} \mathrm{en}=\mathrm{N}, \mathrm{N}$-dimethylethylenediamine, 8 -amq $=8$-aminoquinoline, 1,8-damnph =1,8-diaminonaphthalene, isq = isoquinoline, 3-ampy = 3-aminopyridine, 4-az-py = 4-azidopyridine, 4-OM-py = 4-methoxypyridine, DMP = 2-[3,5-dimethyl-1H-pyrazol-1ylmethyl)]pyridine, bepza $=[$ bis (2-pyrazol-1H-yl)ethyl $)]$ amine, bedmpza $==[$ bis $((3,5$-dimethyl $)-2$-pyrazol-1 $H$-yl $)$ ethyl $)]$ amine.

\subsection{Luminescence Emission}

The optical properties of the synthesized pseudo-halido-zinc(II) complexes were investigated in methanol by UV-Vis and luminescence spectroscopy. To examine the effect of the pseudohalide on the luminescence emission, the TPA series of $[\mathrm{Zn}(\mathrm{TPA})(\mathrm{X})] \mathrm{ClO}_{4}$ $\left(\mathrm{X}=\mathrm{NCS}^{-}, \mathbf{4} ; \mathrm{X}=\mathrm{N}_{3}{ }^{-}, \mathbf{4 a}[68] ; \mathrm{X}=\mathrm{dca}, \mathbf{4 b}\right.$ [72]) were studied. These complexes, together with containing a TPA ligand, show two absorption bands centered around 205 and $260 \mathrm{~nm}$, which can be assigned to ligand-centered $\pi-\pi^{*}$ and $n-\pi^{*}$ transitions of the pyridyl rings and those containing $\mathrm{N}$ atoms. As seen in Figure 5, upon photoexcitation at $260 \mathrm{~nm}$, complexes $4,4 \mathrm{a}$ and $4 \mathrm{~b}$ showed pronounced emission maxima at $\sim 450 \mathrm{~nm}$ and a large red shift up to $\Delta \lambda=190 \mathrm{~nm}$ was observed, which can be ascribed to ligand to sensitized charge transfer transition (LCT) from the lowest excited energy states within the whole complex. 
Interestingly, parent ligand-centered charge transfer (LCT) emission in the azido complex $\mathbf{4 a}$ was quenched in $\mathbf{4}$ and $\mathbf{4 b}$. In addition, it is noted from normalized emission intensities that complex 4a with $\mathrm{N}_{3}{ }^{-}$exhibited the strongest luminescence at $\sim 450 \mathrm{~nm}$ among the TPA series (Figure 5, left). The luminescence of $4 \mathbf{a}$ is found to be nearly 1.6 times greater than the visible luminescence of complex $4 \mathrm{~b}$ with dca.
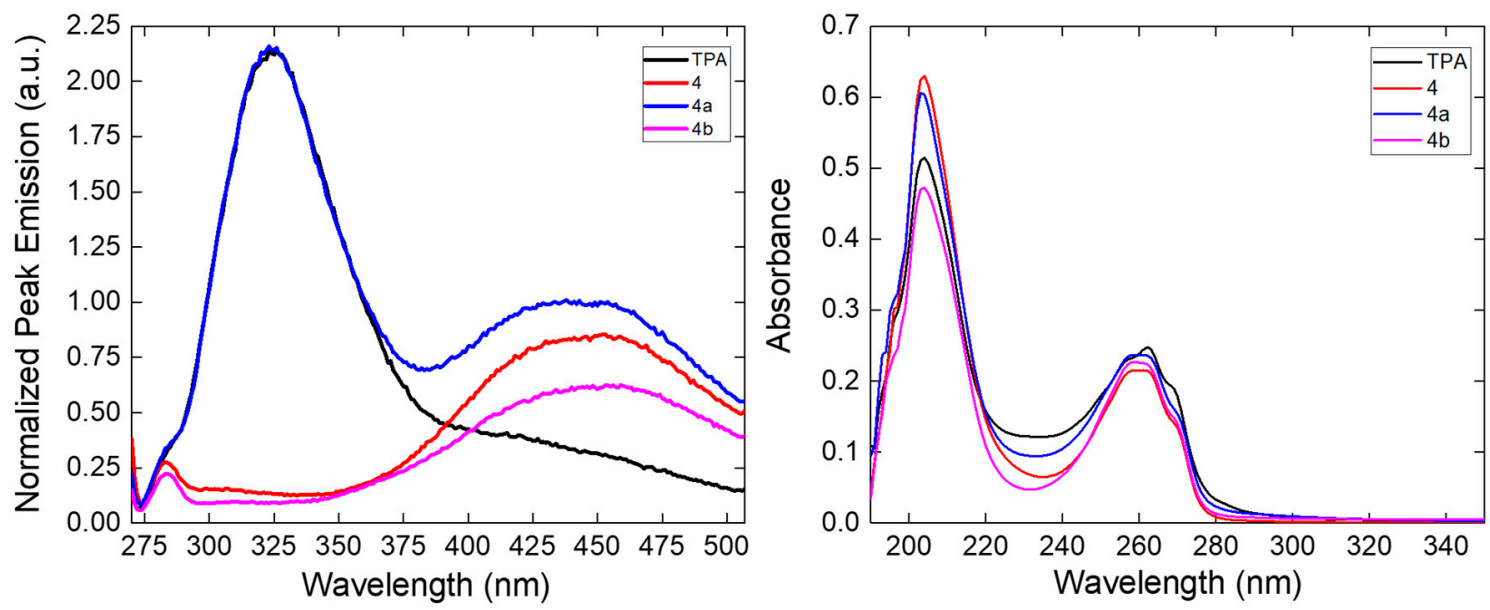

Figure 5. (Left): the normalized emission intensities (represented in reference to complex 4a, which exhibited highest peak intensity) at around $450 \mathrm{~nm}$ at $\lambda_{\mathrm{ex}}=260 \mathrm{~nm}$, and (Right): UV-Vis. absorption spectra for pseudohalido Zn(II)-TPA complexes 4, $4 \mathrm{a}$ and $\mathbf{4 b}$ as well as their parent ligand TPA in methanol.

The influence of the auxiliary ligands, $\mathrm{L}$, was also investigated for the azido compounds, 1, 3 and 4a. As illustrated in Figure 6, all the azido complexes when excited at their second or higher wavelength absorption band displayed luminescence emission peaks associated with LCT transitions (Figure 6, UV spectra). These complexes show bathochromic shifts consistent with their corresponding electronic absorption spectra. Therein, Complex 1 showed the largest bathochromic shift $(\Delta \lambda=115 \mathrm{~nm})$ with the emission peak maximum centered at $375 \mathrm{~nm}\left(\lambda_{\mathrm{ex}}=260 \mathrm{~nm}\right)$. Comparison of the absolute emission intensities' wavelengths and UV-Vis. spectra of the dicyanamido Zn(II) complexes 2, 5, 6, 7 and 8 containing different coordinating ligands in methanol was performed (Figure S7, SM). Therein, complex 5 shows the strongest visible fluorescence peak at $421 \mathrm{~nm}\left(\lambda_{\mathrm{ex}}=330 \mathrm{~nm}\right)$. The UV-Vis. spectrum 5 (Figure S7-Right, SM) exhibits a broad absorption peak center around $330 \mathrm{~nm}$, which is assigned to the $\mathrm{n}-\pi^{*}$ transition of the amino group and another absorption peak in the UV region at $230 \mathrm{~nm}$ ascribed to the $\pi-\pi^{*}$ transition of the naphthalene system. The fluorescence quantum yield (FL QY) of the complex is estimated to be around $9 \%$ and close to the quantum yield (QY) of 1,8-diaminonaphthalene ligand in methanol [73]. The absolute emission intensities of 2 and 7, seen in the UV region, roughly determined to be $\sim 6.8$ - and $\sim 9$-fold, respectively, are lower than the reference complex 5 (Figure S7-FL, $\mathrm{SM})$. The complexes $\left[\mathrm{Zn}(8-\mathrm{amq})_{2}(\mathrm{dca})\right] \mathrm{ClO}_{4}(6)$ and catena-[Zn(N,N-Me $\left.\mathrm{en}_{2}\right)\left(\mu_{1,5}\right.$-dca $\left.)\right] \mathrm{dca}$ (8) did not show any detectable luminescence emission spectra (Figure S7) because of the fluorescence quenching of the 8 -amq in polar protic solvents due to hydrogen bonding with the $\mathrm{MeOH}$ [74] in the former complex and the lack of $\pi-\pi^{*}$ transition in the $N, N-\mathrm{Me}_{2}$ en of Complex 8 . 

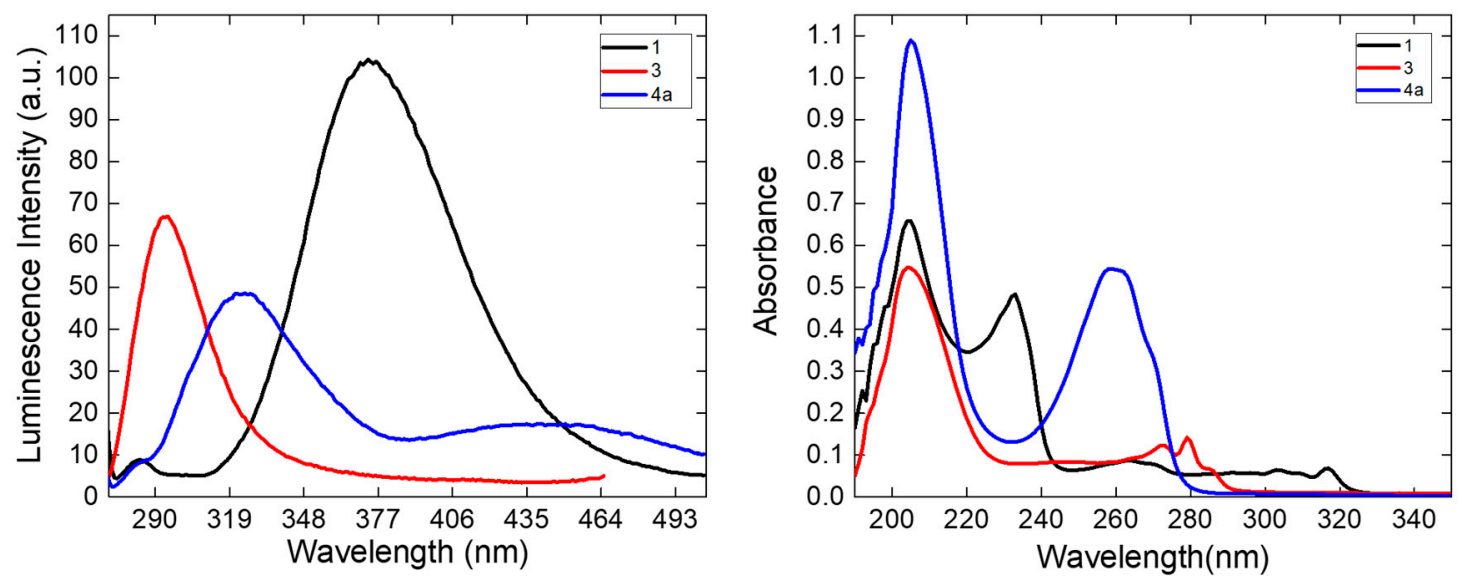

Figure 6. Left: luminescence emission $\left(\lambda_{\mathrm{ex}}=260 \mathrm{~nm}\right)$, and Right: UV-Vis. absorption spectra of Zn(II)-azido complexes 1, 3 and $4 \mathbf{a}$ in methanol.

The fluorescence quantum yield (FL QY) of complex 5 is estimated to be around $9 \%$ and close to the QY of 1,8-diaminonaphthalene ligand in methanol [73]. The absolute emission intensities of 2 and 7, seen in the UV region, roughly determined to be $\sim 6.8$ - and $\sim 9$-fold, respectively, are lower than the reference complex 5 (Figure S7-FL, SM). The complexes $\left[\mathrm{Zn}(8-\mathrm{amq})_{2}(\mathrm{dca})\right] \mathrm{ClO}_{4}(\mathbf{6})$ and catena-[Zn $\left.\left(N, N-\mathrm{Me}_{2} \mathrm{en}\right)\left(\mu_{1,5}-\mathrm{dca}\right)\right] \mathrm{dca}(8)$ did not show any detectable luminescence emission spectra (Figure S7) because of the fluorescence quenching of the 8-amq in polar protic solvents due to hydrogen bonding with the $\mathrm{MeOH}$ [74] in the former complex and the lack of $\pi-\pi^{*}$ transition in the $N, N-\mathrm{Me}_{2}$ en of complex 8 . The FL QY of the pseudohalido-Zn(II) complexes under investigation in $\mathrm{MeOH}$ together with $\lambda_{\max }$ absorption and emission is tabulated in Table 3. The FL QY of all complexes was measured in $\mathrm{MeOH}$ by an optically dilute relative method using 1,8 diaminonaphthalene (1,8-damnaph) as a fluorescent standard of known QY in methanol [73].

Table 3. The $\lambda_{\max }$ absorption, $\lambda_{\max }$ emission, and FL QY of the pseudohalido-Zn(II) complexes under investigation in $\mathrm{MeOH}$.

\begin{tabular}{|c|c|c|c|}
\hline Complex & $\begin{array}{c}\lambda_{\max } \text { Absorption or } \\
\lambda_{\mathrm{ex}}(\mathrm{nm})\end{array}$ & $\lambda_{\text {em }} \begin{array}{c}\text { Emission } \\
(\mathrm{nm})\end{array}$ & FL QY \\
\hline$\left[\mathrm{Zn}(\right.$ Meepmqa $\left.)\left(\mathrm{N}_{3}\right)_{2}\right](\mathbf{1})$ & 260 & 373 & $2.62 \%$ \\
\hline$\left[\mathrm{Zn}(\right.$ Meepmqa)(dca) $] \mathrm{ClO}_{4} \cdot 1 / 2 \mathrm{H}_{2} \mathrm{O}(2)$ & 260 & 373 & $1.15 \%$ \\
\hline$\left[\mathrm{Zn}(\mathrm{NTB})\left(\mathrm{N}_{3}\right)\right] \mathrm{ClO}_{4} \cdot 1 / 2 \mathrm{H}_{2} \mathrm{O}(3)$ & 240 & 294 & $0.98 \%$ \\
\hline$\left[\mathrm{Zn}(\mathrm{TPA})(\mathrm{NCS}) \mathrm{ClO}_{4}(4)\right.$ & 260 & 450 & $0.67 \%$ \\
\hline$\left[\mathrm{Zn}(\mathrm{TPA})\left(\mathrm{N}_{3}\right)\right] \mathrm{ClO}_{4}(\mathbf{4 a})$ & 260 & 324,450 & $1.50 \%$ \\
\hline$[\mathrm{Zn}(\mathrm{TPA})(\mathrm{NCS})] \mathrm{NO}_{3} \cdot 1 / 2 \mathrm{H}_{2} \mathrm{O}(4 \mathbf{b})$ & 260 & 450 & $0.50 \%$ \\
\hline$\left[\mathrm{Zn}(1,8 \text {-damnph })_{2}(\mathrm{dca})_{2}\right](5)$ & 330 & 421 & $9.00 \%$ \\
\hline$\left[\mathrm{Zn}(8-\mathrm{amq})_{2}(\mathrm{dca}) \mathrm{ClO}_{4}(6)\right.$ & 260 & 323 & $0.25 \%$ \\
\hline$\left[\mathrm{Zn}(\mathrm{isq})_{2}\left(\mu_{1,5}-\mathrm{dca}\right)_{2}\right](7)$ & 260 & 335 & $0.56 \%$ \\
\hline
\end{tabular}

The luminescence emission observed in the complexes 3-6a may be attributed to the $\mathrm{CHE}$ effect, which tends to reduce energy loss via radiationless thermal vibrations, and the intraligand $\pi^{*}-\pi$ emission band may shift due to perturbations in the electronic states of the ligands upon coordination with $\mathrm{Zn}^{2+}$ ions [52,53]. Attempts made to correlate the fluorescence enhancements to the rigidity of chelation or to strong $\mathrm{Zn}-\mathrm{N}_{\mathrm{av}}$ (amine) bond lengths were unsuccessful. For example, in the case of $\mathrm{Zn}$-TPA series, all $\mathrm{Zn}-\mathrm{N}_{\mathrm{av}}$ (TPA): 2.111 (4), 2.111 (4a) [68] and $2.094 \AA$ (4b) [72] were very close to providing a satisfactory 
explanation for the fluorescence enhancement differences between the three TPA complexes, and in some cases the lack of crystal structures as compounds $\mathbf{1}$ and $\mathbf{2}$.

\section{Conclusions}

In this study, the interaction of $\mathrm{Zn}(\mathrm{II})$ perchlorate or nitrate with pseudohalides and in the presence of $\mathrm{N}$-donor auxiliary ligands resulted in the formation of a series of mononuclear five-coordinate complexes, including $\left[\mathrm{Zn}(\mathrm{NTB})\left(\mathrm{N}_{3}\right)\right] \mathrm{ClO}_{4} \cdot 1 / 2 \mathrm{H}_{2} \mathrm{O}$ (3), $\left[\mathrm{Zn}(\mathrm{TPA})(\mathrm{NCS}) \mathrm{ClO}_{4}(4)\right.$ and two distorted octahedral $\left[\mathrm{Zn}(1,8-\text { damnph })_{2}(\mathrm{dca})_{2}\right](5)$ and [Zn $\left.(8 \text {-amq })_{2}(\mathrm{dca})_{2}\right](\mathbf{6 a})$ as well as two $1 \mathrm{D}$ polymeric chains catena-[Zn(isq $\left.)_{2}\left(\mu_{1,5} \text {-dca }\right)_{2}\right]$ (7) and catena-[Zn(N,N-Me $\left.\left.e_{2}\right)_{2}\left(\mu_{1,5}-\mathrm{dca}\right)\right] \mathrm{dca}(8)$. The compounds $[\mathrm{Zn}(\mathrm{TPA})(\mathrm{X})] \mathrm{ClO}_{4}$ ( $\mathrm{X}=\mathrm{NCS}^{-}, \mathrm{N}_{3}{ }^{-}$, dca) display luminescence emission maxima in methanol at $\sim 450 \mathrm{~nm}$ with a large red shift up to $\Delta \lambda=190 \mathrm{~nm}$. The effect of different auxiliary ligands, $\mathrm{L}$, on the emission spectra examined in the azido and dicyanamido series revealed that the strongest visible fluorescence peak at $421 \mathrm{~nm}\left(\lambda_{\mathrm{ex}}=330 \mathrm{~nm}\right)$ was observed in [ $\mathrm{Zn}(1,8$ damnph $\left.)_{2}(\mathrm{dca})_{2}\right]$ (5) and, as expected, there was no detectable luminescence emission in 8 due to the lack of $\pi-\pi^{*}$ nor 6 due to fluorescence quenching in MeOH [74]. The comparison of our series together and the structurally characterized other related Zn(II)-pseudohalido complexes with the corresponding Cd(II) analogues clearly showed that the prediction of the $\mathrm{Zn}$ (II) structure based on a structurally characterized Cd(II) analogue or vice versa is not an easy query.

Supplementary Materials: The following are available online at https:/ /www.mdpi.com/article/10 .3390/inorganics9070053/s1, Figure S1: Packing plots of 3, Figure S2: Packing plots of 4, Figure S3: Packing plot of 5, Figure S4: Packing plot of 6a, Figure S5: Packing plot of 7, Figure S6: Packing plot of 8, Figure S7: Fluorescence and UV-Vis. spectra of the dicyanamido Zn(II) complexes 2, 5, 6, 7 and 8 in methanol, Table S1: Selected bond distances $(\AA)$ and bond angles $\left({ }^{\circ}\right)$ of $3,4,5,6 \mathbf{a}, 7$ and 8 , Table S2: Possible hydrogen bonds, Table S3: ring ring interactions in 7. CCDC 2089669-2089674 contain the supplementary crystallographic data for 3, 4, 5, 6a.

Author Contributions: F.A.M., R.C.F. and A.T. performed the X-ray structural analysis. A.R.D., S.F.A., N.M.H.S., F.R.L. and S.S.M. contributed to the synthesis and spectral characterization of the compounds. S.P.S., F.R.L. and S.S.M. in studying the luminescence properties of the complexes. F.A.M., N.M.H.S., F.R.L. and S.S.M. contributed to the writing of the manuscript. All authors have read and agreed to the published version of the manuscript.

Funding: Financial support of this work came from the Department of Chemistry at UL Lafayette by F.R.L. and S.S.M.

Acknowledgments: S.S.M. and F.R.L. thank the Department of Chemistry (UL Lafayette) for funding this work.

Conflicts of Interest: The authors declare no conflict of interest.

\section{References}

1. Maret, W. Zinc in cellular regulation: The Nature and significance of "Zinc Signals". Int. J. Mol. Sci. 2017, 18, 2285. [CrossRef] [PubMed]

2. Zinc (In Biological Systems). In Van Nostrand's Scientific Encyclopedia; Wiley Online: Hoboken, NJ, USA, 2006. [CrossRef]

3. Osredkar, J.; Sustar, N. Copper and Zinc, Biological Role and Significance of Copper/Zinc Imbalance. J. Clinic Toxicol. 2011, 3. [CrossRef]

4. Sigel, H.; Bruce Martin, R. The colorless 'chameleon' or the peculiar properties of $\mathrm{Zn}^{2+}$ in complexes in solution. Quantification of equilibria involving a change of the coordination number of the metal ion. Chem. Soc. Rev. 1994, 23, 83-91. [CrossRef]

5. Maret, W.; Moulis, J.-M. The bioinorganic chemistry of cadmium in the context of its toxicity. In Cadmium: From Toxicity to Essentiality; (Book Series); Sigel, A., Sigel, H., Sigel, R.K.O., Eds.; Springer: Dordrecht, The Netherlands; Berlin/Heidelberg, Germany; New York, NY, USA; London, UK, 2011; Volume 11. [CrossRef]

6. Burgess, J.; Prince, R.H. Inorganic \& Coordination Chemistry: Zinc: Inorganic \& Coordination Chemistry. In The Encyclopedia of Inorganic and Bioinorganic Chemistry, 1st ed.; John Wiley \& Sons, Ltd. (Wiley Online Library): Hoboken, NJ, USA, 2011. [CrossRef]

7. Dudev, T.; Lim, C. Tetrahedral vs octahedral zinc complexes with ligands of biological interest: A DFT/CDM study. J. Am. Chem. Soc. 2000, 122, 11146-11153. [CrossRef] 
8. Mautner, F.A.; Scherzer, M.; Berger, C.; Fischer, R.C.; Massoud, S.S. Synthesis, characterization, and luminescence properties of zinc(II) complexes of pseudohalides and nitrite derived from 4-azido-pyridine. Inorg. Chim. Acta 2015, 425, 46-51. [CrossRef]

9. Mautner, F.A.; Berger, C.; Dartez, M.J.; Nguyen, Q.L.; Favreau, J.; Massoud, S.S. Cadmium(II) and zinc(II) azido complexes with different nuclearity and dimensionality. Polyhedron 2014, 69, 48-54. [CrossRef]

10. Nath, J.; Tarai, A.; Baruah, J.B. Copper(II), zinc(II), and cadmium(II) formylbenzoate complexes: Reactivity and emission properties. ACS Omega 2019, 4, 18444-18455. [CrossRef]

11. Massoud, S.S.; Louka, F.R.; Obaid, Y.K.; Vicente, R.; Ribas, J.; Fischer, R.C.; Mautner, F.A. Metal ions directing the geometry and nuclearity of azido-metal(II) complexes derived from bis(2-(3,5-dimethyl-1H-pyrazol-1-yl)ethyl)amine. Dalton Trans. 2013, 42, 3968-3978. [CrossRef]

12. Mautner, F.A.; Fischer, R.C.; Rashmawi, L.G.; Louka, F.R.; Massoud, S.S. Structural characterization of metal(II) thiocyanato complexes derived from bis(2-(1-H-pyrazol-1-yl)ethyl)amine. Polyhedron 2017, 124, 237-242. [CrossRef]

13. Mautner, F.A.; Fischer, R.C.; Williams, B.R.; Massoud, S.S.; Salem, N.M.H. Hexanuclear cadmium(II) cluster constructed from tris(2-methylpyridyl)amine (TPA) and azides. Crystals 2020, 10, 317. [CrossRef]

14. Mautner, F.A.; Jantscher, P.V.; Fischer, R.C.; Torvisco, A.; Reichmann, K.; Salem, N.M.H.; Gordon, K.J.; Louka, F.R.; Massoud, S.S. Coordination polymers in dicyanamido-cadmium(II) with diverse network dimensionalities. Crystals 2021, 11, 181. [CrossRef]

15. Brahma, R.; Baruah, J.B. Self-assemblies of zinc complexes for aggregation-induced emission luminogen precursors. ACS Omega 2020, 5, 3774-3785. [CrossRef] [PubMed]

16. Xhaferaj, N.; Tăbăcaru, A.; Moroni, M.; Senchyk, G.A.; Domasevitch, K.V.; Pettinari, C.; Galli, S. New coordination polymers of zinc(II), copper(II) and cadmium(II) with 1,3-bis(1,2,4-triazol-4-yl)adamantane. Inorganics 2020, 8, 60. [CrossRef]

17. Gusev, A.; Shul'gin, V.; Braga, E.; Zamnius, E.; Kryukova, M.; Linert, W. Luminescent properties of Zn complexes based on tetradentate $\mathrm{N}_{2} \mathrm{O}_{2}$-donor pyrazolone Schiff bases. Dyes Pigments 2020, 183, 108626. [CrossRef]

18. Endo, K.; Liu, Y.; Ube, H.; Nagata, K.; Shionoya, M. Asymmetric construction of tetrahedral chiral zinc with high configurational stability and catalytic activity. Nat. Commun. 2020, 11, 6263. [CrossRef]

19. Gusev, A.; Braga, E.; Baluda, Y.; Kiskin, M.; Kryukova, M.; Karaush-Karmazin, N.; Baryshnikov, G.; Kuklin, A.; Minaev, B.; Ågren, H.; et al. Structure and tunable luminescence in polymeric zinc compounds based on 3-(3-pyridyl)-5-(4-pyridyl)-1,2,4-triazole. Polyhedron 2020, 191, 114768. [CrossRef]

20. Artesani, A.; Gherardi, F.; Nevin, A.; Gianluca Valentini, G.; Comelli, D. A Photoluminescence study of the changes induced in the zinc white pigment by formation of zinc complexes. Materials 2017, 10, 340. [CrossRef] [PubMed]

21. Cheng, G.; So, G.K.-M.; To, W.-P.; Chen, Y.; Kwok, C.-C.; Ma, C.; Guan, X.; Chang, X.; Kwoke, W.-M.; Che, C.-M. Luminescent zinc(ii) and copper(i) complexes for high-performance solution-processed monochromic and white organic light-emitting devices. Chem. Sci. 2015, 6, 4623-4635. [CrossRef]

22. Dumur, F.; Contal, E.; Wantz, G.; Gigmes, D. Photoluminescence of zinc complexes: Easily tunable optical properties by variation of the bridge between the imido groups of Schiff Base ligands. Eur. J. Inorg. Chem. 2014, 2014, 4186-4198. [CrossRef]

23. Gusev, A.; Shul'gin, V.; Brag, E.; Zamnius, E.; GalinaStarov, G.; Lyssenko, K.; Eremenko, I.; Linert, W. Luminescent properties of zinc complexes of 4-formylpyrazolone based azomethine ligands: Excitation-dependent emission in solution. J. Lumin. 2018, 202, 370-376. [CrossRef]

24. Haas, R.M.; Arshad, M.; Anthony, J.; Altmann, P.J.; Pöthig, A.; Köhler, F.H.; Hess, C.R. Six- and seven-coordinate Fe(II) and Zn(II) compounds ligated by unsymmetric xanthene-based ligands: Characterization and magnetic properties. Inorg. Chem. Front. 2016, 3, 616-629. [CrossRef]

25. Sarkar, B.N.; Bhar, K.; Chattopadhyay, S.; Das, S.; Mitra, P.; Ghosh, B.K. Synthesis, structure and luminescence behavior of heptacoordinated one-dimensional coordination polymers of the type $[\mathrm{Cd}(\mathrm{L})(\mathrm{dca})]_{\mathrm{n}}(\mathrm{X})_{\mathrm{n}}(\mathrm{L}=$ a pentadentate Schiff base; dca = dicyanamide; $\mathrm{X}=\mathrm{ClO}_{4}{ }^{-}, \mathrm{PF}_{6}{ }^{-}$). J. Mol. Struct. 2010, 963, 35-40. [CrossRef]

26. Chisholm, M.H.; Gallucci, J.C.; Zhen, H.; Huffman, J.C. Three-coordinate zinc amide and phenoxide complexes supported by a bulky Schiff Base ligand. Inorg. Chem. 2001, 40, 5051-5054. [CrossRef]

27. Pang, K.; Rong, Y.; Parkin, G. Molecular structures of three coordinate zinc and cadmium complexes that feature $\beta$-diketiminato and anilido-imine ligands. Polyhedron 2010, 29, 1881-1890. [CrossRef]

28. Mautner, F.A.; Louka, F.R.; Hofer, J.; Spell, M.; Lefèvre, A.; Guilbeau, A.E.; Massoud, S.S. One-dimensional cadmium polymers with alternative $\operatorname{di}(\mathrm{EO} / \mathrm{EE})$ and $\operatorname{di}(\mathrm{EO} / \mathrm{EO} / \mathrm{EO} / \mathrm{EE})$ bridged azide bonding modes. Cryst. Growth Des. 2013, 13, 4518-4525. [CrossRef]

29. Mautner, F.A.; Berger, C.; Gspan, C.; Yana, B.; Fischer, R.C.; Massoud, S.S. Pyridyl and triazole ligands directing the assembling of zinc(II) into coordination polymers with different dimensionality through azides. Polyhedron 2017, 130, 136-144. [CrossRef]

30. Mautner, F.A.; Jantscher, P.; Fischer, R.C.; Torvisco, A.; Vicente, R.; Karsili, T.N.V.; Massoud, S.S. Synthesis and characterization of $1 \mathrm{D}$ coordination polymers of metal(II)-dicyanamido complexes. Polyhedron 2019, 166, 36-43. [CrossRef]

31. Mautner, F.A.; Scherzer, M.; Berger, C.; Fischer, R.C.; Vicente, R.; Massoud, S.S. Synthesis and characterization of three new 1-D polymeric $\left.\left[\mathrm{M}_{2} \text { (4-azidopyridine }\right)_{4}\left(\mu_{1,1}-\mathrm{N}_{3}\right)_{2}\left(\mu_{1,3}-\mathrm{N}_{3}\right)_{2}\right]_{\mathrm{n}}(\mathrm{M}=\mathrm{Ni}, \mathrm{Co}, \mathrm{Cd})$ complexes. Polyhedron 2015, 85, 329-336. [CrossRef]

32. Mautner, F.A.; Traber, M.; Fischer, R.C.; Massoud, S.S.; Vicente, R. Synthesis, crystal structures, spectral and magnetic properties of 1-D polymeric dicyanamido metal(II) complexes. Polyhedron 2017, 138, 13-20. [CrossRef]

33. $\mathrm{Xu}, \mathrm{H}$; Guo, C. catena-poly[[(8-aminoquinoline- $\left.\kappa^{2} N, N^{\prime}\right)$ cadmium $]-$ di- $\mu$-thioyanate- $\kappa^{2} \quad N: S ; \kappa^{2} \quad S: N-\left[\left(8\right.\right.$-aminoquinoline- $\kappa^{2}$ $N, N^{\prime}$ )cadmium]-di- $\mu$-chlorido]. Acta Crystallogr. Sect. E Struct. Rep. Online 2012, 68, m3. [CrossRef] 
34. Xu, H.; Huang, L.-F.; Guo, L.-M.; Zhang, Y.-F.; Ren, X.-M.; Song, Y.; Xie, J. Three green luminescent cadmium complexes containing 8-aminoquinoline ligands: Syntheses, crystal structures, emission spectra and DFT calculations. J. Lumin. 2008, 128, 1665-1672. [CrossRef]

35. Cui, P.; Chen, Z.; Gao, D.; Zhao, B.; Shi, W.; Cheng, P. Syntheses, structures, and photoluminescence of a series of three-dimensional Cd(II) frameworks with a flexible ligand, 1,5-bis(5-tetrazolo)-3-oxapentane. Cryst. Growth Des. 2010, 10, 4370-4378. [CrossRef]

36. Ding, B.; Li, J.; Yang, E.-C.; Wang, X.-G.; Zhao, X.-J. Synthesis, structure, and characterization of a novel one-dimensional tube-like cadmium coordination polymer. Z. Anorg. Allg. Chem. 2007, 633, 1062-1065. [CrossRef]

37. Jurgens, B.; Irran, E.; Hoppe, H.A.; Schnick, W. Phase transition of a dicyanamide with rutile-like structure: Syntheses and crystal structures of $\alpha$ - and $\beta-\mathrm{Cd}\left[\mathrm{N}(\mathrm{CN})_{2}\right]_{2}$. Z. Anorg. Allg. Chem. 2004, 630, 219-223. [CrossRef]

38. Adhikary, C.; Koner, S. Structural and magnetic studies on copper(II) azido complexes. Coord. Chem. Rev. 2010, 254, 2933-2958. [CrossRef]

39. Louka, F.R.; Massoud, S.S.; Haq, T.K.; Koikawa, M.; Mikuriya, M.; Omote, M.; Fischer, R.C.; Mautner, F.A. Synthesis, structural characterization, and magnetic properties of one-dimensional $\mathrm{Cu}(\mathrm{II})$-azido coordination polymers. Polyhedron 2017, 138, 177-184 [CrossRef]

40. Mautner, F.A.; Scherzer, M.; Berger, C.; Fischer, R.C.; Vicente, R.; Massoud, S.S. Synthesis and characterization of five new thiocyanato- and yanate-metal(II) complexes with 4-azidopyridine as co-ligand. Polyhedron 2015, 85, 20-26. [CrossRef]

41. Batten, R.S.; Murray, R.K. Structure and magnetism of coordination polymers containing dicyanamide and tricyanomethanide. Coord. Chem. Rev. 2003, 246, 103-130. [CrossRef]

42. Wang, S. Luminescence, and electroluminescence of $\mathrm{Al}(\mathrm{III}), \mathrm{B}(\mathrm{III}), \mathrm{Be}(\mathrm{II})$ and $\mathrm{Zn}(\mathrm{II})$ complexes with nitrogen donors. Coord. Chem. Rev. 2001, 215, 79-98. [CrossRef]

43. Li, Y.; Shi, L.; Qin, L.-X.; Qu, L.-L.; Jing, C.; Lan, M.; James, T.D.; Long, Y.-T. An OFF-ON fluorescent probe for Zn ${ }^{2+}$ based on a GFP-inspired imidazolone derivative attached to a 1,10-phenanthroline moiety. Chem. Commun. 2011, 47, 4361-4363. [CrossRef] [PubMed]

44. Liu, J.-Q.; Luo, Z.-D.; Pan, Y.; Singh, A.K.; di Trive, M.; Kumar, A. Recent developments in luminescent coordination polymers: Designing strategies, sensing application and theoretical evidences. Coord. Chem. Rev. 2020, 406, 213145. [CrossRef]

45. Gu, J.-Z.; Liang, X.-X.; Cai, Y.; Wu, J.; Shi, Z.-F.; Kirillov, A.M. Hydrothermal assembly, structures, topologies, luminescence, and magnetism of a novel series of coordination polymers driven by a trifunctional nicotinic acid building block. Dalton Trans. 2017, 46, 10908-10925. [CrossRef] [PubMed]

46. Heine, J.; Müller-Buschbaum, K. Engineering metal-based luminescence in coordination polymers and metal-organic frameworks. Chem. Soc. Rev. 2013, 42, 9232-9242. [CrossRef]

47. De Silva, A.P.; Fox, D.P.; Huxley, A.J.M.; Moody, T.S. Combining luminescence, coordination, and electron transfer for signaling purposes. Coord. Chem. Rev. 2000, 205, 41-57. [CrossRef]

48. Alam, R.; Bhowmick, R.; Islam, A.S.M.; Chaudhuri, K.; Ali, M. A rhodamine based fluorescent trivalent sensor $\left(\mathrm{Fe}^{3+}, \mathrm{Al}^{3+}, \mathrm{Cr}^{3+}\right)$ with potential applications for live cell imaging and combinational logic circuits and memory devices. New J. Chem. 2017, 41, 8359-8369. [CrossRef]

49. Aragoni, M.C.; Arca, M.; Bencini, A.; Caltagirone, C.; Garau, A.; Isaia, F.; Light, M.E.; Lippolis, V.; Lodeiro, C.; Mameli, M. $\mathrm{Zn}^{2+} / \mathrm{Cd}^{2+}$ optical discrimination by fluorescent chemosensors based on 8-hydroxyquinoline derivatives and sulfur-containing macrocyclic units. Dalton Trans. 2013, 42, 14516-14530. [CrossRef]

50. Lee, H.; Lee, H.S.; Reibenspies, J.H.; Hancock, R.D. Mechanism of "turn-on" fluorescent sensors for mercury(II) in solution and its implications for ligand design. Inorg. Chem. 2012, 51, 10904-10915. [CrossRef]

51. Deems, J.C.; Reibenspies, J.H.; Lee, H.-S.; Hancock, R.D. Strategies for a fluorescent sensor with receptor and fluorophore designed for the recognition of heavy metal ions. Inorg. Chim. Acta 2020, 499, 119181. [CrossRef]

52. Lee, H.; Hancock, R.D.; Lee, H.S. Role of fluorophore-metal interaction in photoinduced electron transfer (PET) sensors: Timedependent density functional theory (TDDFT) study. J. Phys. Chem. A 2013, 117, 13345-13355. [CrossRef]

53. Rosita, D.; Panunzi, B. The role of zinc(II) ion in fluorescence tuning of tridentate pincers: A Review. Molecules 2020, $25,4984$. [CrossRef]

54. Oki, A.R.; Bommarreddy, P.R.; Zhang, H.; Nosmane, N. Manganese(II) complex of the 'tripod' ligand tris(2-benzimidazolylmethyl)amine. Five-coordinate and six-coordinate Mn(II) in the crystal structure. Inorg. Chim. Acta 1995, 231, 109-114. [CrossRef]

55. Anderegg, G.; Wenk, F. Pyridine derivatives as complexing agents. VIII. Preparation of a new quadridentate and a new hexadentate ligand. Helv. Chim. Acta 1967, 50, 2330. [CrossRef]

56. Tyekla'r, Z.; Jacobson, R.R.; Wei, N.; Murthy, N.N.; Zubieta, J.; Karlin, K.D. Reversible reaction of dioxygen (and carbon monoxide) with a copper(I) complex. X-ray structures of relevant mononuclear $\mathrm{Cu}(\mathrm{I})$ precursor adducts and the trans-( $\mu 1,2-$ peroxo)dicopper(II) product. J. Am. Chem. Soc. 1993, 115, 2677-2689. [CrossRef]

57. Bruker (2005); SAINT v. 7.23; Bruker AXS Inc.: Madison, WI, USA, 2005.

58. Bruker (2006); APEX 2, v. 2.0-2; Bruker AXS Inc.: Madison, WI, USA, 2005.

59. Sheldrick, G.M. SADABS v. 2; University of Goettingen: Goettingen, Germany, 2001.

60. Sheldrick, G.M. A short history of SHELX. Acta Crystallogr. 2008, A64, 112-122. [CrossRef]

61. Sheldrick, G.M. Crystal structure with SHELX. Acta Crystallogr. 2015, C71, 3-8. 
62. Macrae, C.F.; Edington, P.R.; McCabe, P.; Pidcock, E.; Shields, G.P.; Taylor, R.; Towler, T.; van de Streek, J. Mercury: Visualization and analysis of crystal structures. J. Appl. Cryst. 2006, 39, 453-457. [CrossRef]

63. Speck, A.L. PLATON, a Multipurpose Crystallographic Tool; Utrecht University: Utrecht, The Netherlands, 2001.

64. Geary, W.J. The use of conductivity measurements in organic solvents for the characterization of coordination compounds. Coord. Chem. Rev. 1971, 7, 81-122. [CrossRef]

65. Mautner, F.A.; Albering, J.H.; Harrelson, E.V.; Gallo, A.A.; Massoud, S.S. N-Bonding vs. S-bonding in thiocyanato-copper(II) complexes. J. Mol. Struct. 2011, 1006, 570-575. [CrossRef]

66. Köhler, H.; Kolbe, A.; Lux, G. Metall-pseudohalogenide. 27. Zur Struktur der Dicyanamide zweiwertiger 3d-metalle M(N(CN) $)_{2}$. Z. Anorg. Allg. Chem. 1977, 428, 103-112. [CrossRef]

67. Addison, A.W.; Rao, T.N.; Reedijk, J.; Rijin, J.V.; Verschoor, G.C. Synthesis, structure, and spectroscopic properties of copper(II) compounds containing nitrogen-sulphur donor ligands; the crystal and molecular structure of aqua[1,7-bis(Nmethylbenzimidazol-20 -yl)-2,6-dithiaheptane]copper(II) perchlorate. J. Chem. Soc. Dalton Trans. 1984, 7, 1349-1356. [CrossRef]

68. Dahl, E.W.; Kiernicki, J.J.; Zeller, M.; Szymczak, N.K. Hydrogen bonds dictate $\mathrm{O}_{2}$ Capture and release within a zinc tripod. J. Am. Chem. Soc. 2018, 140, 10075-10079. [CrossRef]

69. Zhao, D.; Zhao, E.-X.; Huan, C.-A. Syntheses and characterizations of three new coordination compounds: $\left[\mathrm{M}\left(\mathrm{C}_{9} \mathrm{NH}\right)_{4}(\mathrm{SCN})_{2}\right]$ $(\mathrm{M}=\mathrm{Zn}, \mathrm{Cd})$ and $\left[\mathrm{Zn}\left(\mathrm{C}_{9} \mathrm{NH}_{7}\right)_{2}(\mathrm{SCN})_{2}\right]$ with a pseudo-merohedral twinning structure. Synth. React. Inorg. Met. Org. Nano-Met. Chem. 2014, 44, 1390-1397. [CrossRef]

70. Xu, H.; Liu, G.-X.; Huang, R.-Y.; Zhao, S.-P.; Kong, X.-J. Synthesis, Crystal Structure, Luminescence Property and DFT Calculations of a New Coordination Compound Containing 8-Aminoquinoline Ligand. Jiegou Huaxue (Chin.) (Chin. J. Struct. Chem.) 2013, 32, 545.

71. Xu, H.; Huang, L.-F.; Ren, X.-M. Synthesis, crystal structure and fluorescence properties of the green fluorescent complex 8-aminoquinoline cadmium thiocyanate. Wuji Huaxue Xuebao (Chin.) (Chin. J. Inorg. Chem.) 2010, 26, 171.

72. Li, H.; Zhao, H.Y.; Zhang, S.G. (Dicyanamido)[tris-(2-pyridylmeth-yl)amine]zinc(II) perchlorate. Acta Crystallogr. Sect. E Struct. Rep. Online 2008, 64, m495. [CrossRef]

73. Lamperti, M.; Giani, A.M.; Maspero, A.; Vesco, G.; Cimino, A.; Negri, R.; Giovenzana, G.B.; Palmisano, G.; Mella, M.; Nardo, L. Synthesis and spectroscopic characterization of 2-(het)Aryl perimidine derivatives with enhanced fluorescence quantum yields. $J$. Fluoresc. 2019, 29, 495-504. [CrossRef]

74. Schulman, S.G.; Sanders, L.B. Fluorescence, and phosphorescence of 5- and 8-aminoquinoline. Anal. Chim. Acta 1971, 56, 83-89. [CrossRef] 